WP 16-01

\title{
Moral Hazard and the Energy Efficiency Gap: Theory and Evidence
}

\author{
Louis-Gaëtan Giraudet \\ Ecole des Ponts ParisTech \\ Centre International de Recherche sur l'Environnement et le D'eveloppement (CIRED) \\ Sébastien Houde \\ University of Maryland \\ Department of Agricultural and Resource Economics \\ Joseph Maher \\ University of Maryland \\ National Socio-Environmental Synthesis Center (SESYNC)
}

Copyright (C) 2016 by Louis-Gaëtan Giraudet, Sébastien Houde, and Joseph Maher

All rights reserved. Readers may make verbatim copies of this document for non-commercial purposes by any means, provided that this copyright notice appears on all such copies. 


\title{
Moral Hazard and the Energy Efficiency Gap: Theory and Evidence
}

\author{
Louis-Gaëtan Giraudet, ${ }^{*}$ Sébastien Houde, ${ }^{\dagger}$ Joseph Maher ${ }^{\ddagger}$
}

December 10, 2016

\begin{abstract}
We investigate how moral hazard problems can cause sub-optimal investment in energy efficiency, a phenomenon known as the energy efficiency gap. We focus on contexts where both the quality offered by the energy efficiency provider and the behavior of the energy user are imperfectly observable. We first formalize under-provision of quality and compare two policy instruments: energy-savings insurance and minimum quality standards. Both instruments are second-best, for different reasons. Insurance induce over-use of energy, thereby requiring incomplete coverage in equilibrium. Standards incur enforcement costs. We then provide empirical evidence of moral hazard in the U.S. home retrofit market. We find that for those measures, the quality of which is deemed hard to observe, realized energy savings are subject to day-of-the-week effects. Specifically, energy savings are significantly lower when those measures were installed on a Friday - a day particularly prone to negative shocks on workers' productivity - than on any other weekday. The Friday effect explains $65 \%$ of the discrepancy between predicted and realized energy savings, an increasingly documented manifestation of the energy efficiency gap. We finally parameterize a model of the U.S. market for attic insulation and find that the deadweight loss from moral hazard is important over a range of specifications. Minimum quality standards appear more desirable than energy-savings insurance if energy-use externalities remain unpriced.
\end{abstract}

JEL: D86, Q41

Keywords: Energy efficiency gap, moral hazard, energy-savings insurance, minimum quality standard, credence good, day-of-the-week effect.

${ }^{*}$ Centre International de Recherche sur l'Environnement et le Développement (CIRED), Ecole des Ponts ParisTech. Email: giraudet@centre-cired.fr.

${ }^{\dagger}$ Department of Agricultural and Resource Economics, University of Maryland. Email: shoude@umd.edu.

${ }^{\ddagger}$ National Socio-Environmental Synthesis Center (SESYNC) University of Maryland. Email: jmaher@sesync.org. 


\section{Introduction}

Energy efficiency measures are widely advocated as a means of both saving money and costeffectively reducing externalities associated with energy use. Yet in practice, they are little adopted. This phenomenon is commonly referred to as the energy efficiency gap. A variety of explanations have been investigated to explain the energy efficiency gap (Gillingham, Newell, and Palmer 2009; Allcott and Greenstone 2012). Jaffe and Stavins (1994), who first conceptualized the problem, emphasized the difference between market-failure and nonmarket failure explanations of the gap. Market failures such as information asymmetries, positive externalities from innnovation or negative externalities from pollution and security of energy supply may distort incentives for energy efficiency investment. This motivates implementation of corrective policies. Non-market failures such as heterogeneity in consumer valuations of energy services or hidden costs (e.g., inconvenience caused by measure installation) may also prevent widespread adoption of energy efficiency. Yet unlike market failures, these are normal components of markets. As such, they should be accounted for in economic assessments but do not per se warrant any particular intervention. More recently, the dichotomy has been enriched with the concept of behavioral anomalies to account for apparent under-valuation of energy savings by energy users (Gillingham and Palmer 2014; Allcott, Mullainathan, and Taubinsky 2014).

Several ex post evaluations of energy efficiency programs also find that realized energy savings underperform those predicted by engineering models (Metcalf and Hassett 1999; Fowlie, Greenstone, and Wolfram 2015; Zivin and Novan 2016; Maher 2016; Davis, Fuchs, and Gertler 2014; Houde and Aldy 2014). This measurement gap between predicted and realized savings can arise from a variety reasons and is subject to an intense debate. ${ }^{1}$ In this paper, we provide a market-failure explanation for the discrepancy between predicted and realized savings: moral hazard in the provision of quality. Combining theoretical, empirical and numerical approaches, we argue that the problem is empirically relevant, economically

\footnotetext{
${ }^{1}$ Fowlie, Greenstone, and Wolfram (2015) investigate the role of the rebound effect, which appears to not play a major role in their context. Davis, Fuchs, and Gertler (2014) discuss the role of inframarginal program participants and the fact that some participants might replace technologies that are not being used in the first place, leading to higher energy consumption after investment. Houde and Aldy (2014) present evidence that consumers might be upgrading toward larger and higher quality models when energy efficiency technologies are subsidized. Other than the reason discussed here, the gap between predicted and realized savings can be attributed to a variety of technical reasons (de Wilde 2014), in particular the so-called prebound-effect, according to which energy use before investment tends to be overestimated in engineering predictions of energy savings (Sunikka-Blank and Galvin 2012).
} 
important and partially remediable by policy interventions such as minimum quality standards and energy-savings insurance.

Our motivation comes from the credence-good nature of energy efficiency, a little-studied aspect of this technology. Just like taxi rides or auto repairs, many energy efficiency measures are subject to verifiability and liability issues which make their performance never completely revealed to the buyer (Sorrell 2004; Dulleck and Kerschbamer 2006). This is especially the case in buildings, where energy use depends on unobservable factors such as weather forecasts, occupants' behaviors and the quality of energy efficiency equipment. These properties are conducive to a set of information asymmetries, of which two have received most attention. One is adverse selection in housing decisions. The intuition is that the energy efficiency of a dwelling is hard to observe and therefore will not be capitalized into sale prices or lease contracts. The intuition is proving correct in rental housing, as rented dwellings are found to be less energy-efficient than owner-occupied ones (Scott 1997; Davis 2012; Gillingham, Harding, and Rapson 2012; Myers 2013; Krishnamurthy and Kriström 2015). The effect is less clear in home sales. More energy-efficient homes, as measured by their energy performance certificate, are found to sell with a premium, but no counterfactual situation without certificates is available for comparison (Brounen and Kok 2011; Murphy 2014; Fuerst, McAllister, Nanda, and Wyatt 2015). Another much-studied information asymmetry associated with energy efficiency is moral hazard in energy demand. It is well established that building occupants use more energy when they face zero marginal cost for energy usage, for instance because they signed up a utility-included rent contract (Levinson and Niemann 2004; Maruejols and Young 2011; Gillingham, Harding, and Rapson 2012).

The information asymmetry considered here is related but involves different parties. We are interested in under-provision of quality in the installation of energy efficiency measures. We specifically examine home energy retrofits, where a contractor may take advantage of the lack of expertise of the homeowner to perform insulation or duct sealing poorly. This can be interpreted as supply-side moral hazard. As we shall see, full analysis of the problem and solutions thereto requires one to also consider the demand-side moral hazard discussed above.

Our contribution is three-fold. First, we formalize how supply-side moral hazard can cause an energy efficiency gap and examine two little-discussed policy remedies: energy-savings insurance, a private solution, and minimum quality standards, a public one. The analysis builds on a double-moral-hazard framework borrowed from the literature on warranties (Cooper and Ross 1985). We articulate the mechanism by which asymmetric information 
induces the contractor to cut quality in equilibrium. This deters adoption of energy efficiency measures. Both policy solutions are found to be second-best: energy-savings insurance reduce marginal energy expenditures, which induces demand-side moral hazard and therefore requires incomplete coverage in equilibrium; minimum quality standards incur enforcement costs.

Second, we provide the first empirical evidence of supply-side moral hazard in home energy retrofits. Using a dataset of more than 4,000 retrofits sponsored by Gainesville Regional Utilities (GRU) in Florida, we exploit variation in the type of measures (classified as easy or hard to observe) and the day of the week on which they were installed. We find that realized energy savings underperform predicted ones, and in particular that the former can vanish for hard-to-observe measures if those were installed on a Friday. The result is robust to a number of robustness checks, including testing for contractors selecting specific measures on Fridays. It suggests that perhaps due to fatigue, retrofit workers are likely to shrink if the informational context gives them the opportunity to do so. Controlling for the Friday effect, the discrepancy between predicted and realized energy savings shrinks by $65 \%$. Incidentally, the exercise contributes to the empirical literature on day-of-the-week effects on workers' productivity (Campolieti and Hyatt 2006; Bryson and Forth 2007) and more generally to the empirical analysis of moral hazard and credence goods (Abbring, Heckman, Chiappori, and Pinquet 2003; Dulleck, Kerschbamer, and Sutter 2011; Schneider 2012; Balafoutas, Beck, Kerschbamer, and Sutter 2013).

Third, we integrate the two approaches and conduct a numerical assessment of the size of and policy solutions to supply-side moral hazard in the context of attic insulation. The model developed in the theoretical exercise is specified and parameterized with data derived from the GRU program and the U.S. Residential Energy Consumption Survey (RECS). We find that the deadweight loss from moral hazard is commensurate with that from energy-use externalities over a number of parameter specifications, in some cases even largely exceeding it. Energy-savings contracts with insurance coverage of about $20 \%$ can mitigate losses, while minimum performance standards deliver benefits which hardly compensate enforcement costs. The merit order is however reversed if energy-use externalities are left unpriced. Then, the demand-side moral hazard induced by insurance magnifies losses and standards appear as the best policy option.

Our analysis is a first step pointing to supply-side moral hazard in home energy retrofits as an important problem, both empirically and economically. Policy instruments already 
existing in the marketplace could be adjusted to deliver their full potential. Energy performance contracts, which are common in commercial buildings, could be promoted in the residential sector. Certification of professional installers, which is so far voluntary, could evolve toward a mandatory regime. Hybrid instruments combining standards and insurance might also produce substantial benefits.

The outline of the paper is as follows. Section 2 introduces the theoretical model, derives key predictions and examines policy solutions. Section 3 presents the empirical approach and the results. Section 4 provides numerical simulations of the U.S. home insulation market to compare policy impacts. Section 5 concludes.

\section{A model of energy efficiency investment with double moral haz- ard}

Our model builds upon the double-moral-hazard model of Cooper and Ross (1985). Investments in energy retrofits for the residential sector, which involve hidden actions from both the homeowner and the contractor, are considered as a canonical example. Other situations that give rise to one-sided moral hazard, for instance energy retrofits in the commercial and industrial sectors, can be viewed as special cases of this general model. They are occasionally discussed in the text. The exposition here focuses on the key elements and predictions of the model. Formal assumptions, additional propositions, complete proofs and graphical illustrations are provided in an online appendix.

\subsection{Setup}

Consider an ower-occupant who uses energy to heat her home. This energy service $s$, measured in indoor temperature, provides her with increasing comfort $V(s)$, multiplied by a taste parameter $\theta>0$. For instance, a person who prefers a high indoor temperature would be characterized with a high value of $\theta$.

The homeowner faces energy expenditure $p E^{0}(s)$, where $E^{0}(\cdot)$ is the energy use and $p$ the price of energy. She sets her energy service $s_{\theta}^{0}$ so as to maximize the discounted sum of net utility:

$$
U^{0}(\theta, s) \equiv\left(\theta V(s)-p E^{0}(s)\right) \Gamma
$$


where $\Gamma$ is a discount factor. ${ }^{2}$

The homeowner can undertake a retrofit investment supplied by a contractor. Each party can take hidden actions that influence ex post energy use, $E(s, q)$. The homeowner's ex post energy service $s$ is unobserved to the contractor. In turn, the quality $q$ with which the contractor completes the retrofit is unobserved to the homeowner, who as a non-expert cannot verify insulation installation or duct sealing, for instance. Energy use, which is reported on the homeowner's utility bill, is common knowledge to both parties, who are also aware that it increases with $s$ and decreases with $q$. The framework is deterministic and linearity of utility with respect to energy expenditures reflects risk-neutrality. ${ }^{3}$

Upon investing, the homeowner maximizes utility $U(\theta, s, q)$, net of upfront cost $T>0$ and including an idiosyncratic value, $\epsilon:{ }^{4}$

$$
U(\theta, s, q) \equiv(\theta V(s)-p E(s, q)) \Gamma-T+\epsilon
$$

The contractor maximizes profit formed by the revenue from the sale $T$ minus the cost $C(\cdot)$ of providing quality $q$. We assume zero profit, so that: $T=C(q)$. The assumption is meant to reflect the competitive nature of the industry. ${ }^{5}$ As we explain in the Online Appendix, the equilibrium analysis is nevertheless robust to alternative market structures.

The energy efficiency contract can be modeled as a two-stage game, of which the homeowner is the principal and the contractor is the agent. In the first stage, the homeowner of type $\theta$ invests if her net present value $N P V(\theta)$ is positive, given her energy service $s_{\theta}^{*}$ and the quality $q_{\theta}^{*}$ she expects to be offered in equilibrium:

\footnotetext{
${ }^{2}$ We assume time invariance of energy price, energy technology and consumer value. The energy service vector is therefore constant over time, which we simplify as a scalar $s$. The discount factor implicitly factors in a discount rate $r$ and an investment lifetime $l$ such that $\Gamma \equiv \Gamma(r, l) \equiv \sum_{t=1}^{l}(1+r)^{-t}=\left(1-(1+r)^{-l}\right) / r$.

${ }^{3}$ We ignore uncertainties coming from the weather variations determining heating needs, from measurement errors propagated in the complex engineering models used to predict energy savings, or from the volatility of energy prices. This simplification is equivalent to assuming that the effects of $s$ and $q$ on energy use both satisfy first-order stochastic dominance.

${ }^{4}$ The term $\epsilon$ captures aesthetic and acoustic benefits associated with the measure, as well as the inconvenience costs incurred forinstallation.

${ }^{5}$ The home energy retrofit industry is highly fragmented. For instance, firms operating in the heating, ventilation and air conditioning (HVAC) industry in California are typically small, offer low wages, face low barriers to entry and an annual turnover as high as 25\% (Zabin, Lester, and Halpern-Finnerty 2011).
} 


$$
N P V(\theta) \equiv U\left(\theta, s_{\theta}^{*}, q_{\theta}^{*}\right)-U_{0}\left(\theta, s_{\theta}^{0}\right) \geq 0
$$

In the second stage, both agents determine their optimal action given their belief about the other party's action. The game is solved using backward induction.

\subsection{Supply-side moral hazard}

The social optimum is modeled as a cooperative game with perfect information. We show in the Online Appendix that this game generates strictly increasing reaction functions: a contractor will offer more quality to a homeowner he perceives as demanding more energy service; the homeowner will demand more energy service is she expects to be offered more quality. The intersection of the two reaction functions defines a perfect-information equilibrium that determines the socially optimal level of quality.

If actions $s$ and $q$ are not perfectly observable, the parties each maximize their private surplus, given their beliefs about the other party's action. This does not affect the homeowner's first-order conditions and therefore leaves her reaction function unchanged. In contrast, the contractor does not to internalize how the quality he provides benefits the homeowner. His reaction function is now flat: whatever behavior he expects from the homeowner, he sets quality at the level which minimizes production cost. The intersection of the two reaction functions defines the asymmetric-information equilibrium.

Equilibrium actions under perfect information $(P I)$ and asymmetric information $(A I)$ can be unambiguously compared:

Proposition 1. Under asymmetric information, an energy efficiency contract is subject to supply-side moral hazard. The contractor offers less quality to any homeowner of type $\theta$ than under perfect information $\left(q_{\theta}^{A I} \leq q_{\theta}^{P I}\right)$. The homeowner responds by using less energy service $\left(s_{\theta}^{0}<s_{\theta}^{A I} \leq s_{\theta}^{P I}\right)$. The two inputs together make investment less profitable $\left(N P V^{A I}(\theta) \leq\right.$ $\left.N P V^{P I}(\theta)\right)$.

The resulting quality gap, which corresponds to under-treatment in the credence-good terminology, would occur even if the homeowner's behavior did not respond to energy expenditures. $^{6}$

\footnotetext{
${ }^{6}$ This is for instance the case with a tenant subscribing to a utility-included rent contract, or an employee in a commercial building. Then, the occupant's reaction function would be flat. The contractor's reaction
} 
Comparison of equilibrium outcomes is ambiguous when it comes to energy use. If consumer behavior were held constant at some $\bar{s}$, as is generally assumed in ex ante engineering simulations, then moral hazard would still produce a wedge between predicted and realized energy savings: $E\left(\bar{s}, q_{\theta}^{A I}\right)>E\left(\bar{s}, q_{\theta}^{P I}\right)$. Yet according to Proposition 1, undoing moral hazard would increase both $q$ and $s$. Recall that by assumption, the two inputs have an opposite effect on $E(\cdot, \cdot)$. Therefore, the decrease in energy use due to increased quality would be partly offset by the increase in energy service. This phenomenon is known as the rebound effect. At some point, it can backfire, that is, be such that energy use is higher after investment. In the presence of negative energy-use externalities, this can have important consequences, as we will see later.

We now extend the above result to the whole market. Consider a continuum of homeowners of mass 1, all living in a similar dwelling and only differing with respect to their preference for energy service $\theta$. We show in the Online Appendix that the higher the value of $\theta$, the higher the demand for energy service, hence the higher the quality offered under perfect information. This shifts the homeowner's reaction function upward. In contrast, the quality offered under asymmetric information remains at minimum. As a result, the moral-hazard effect is increasing in $\theta$. We also show that the net present value of investment is increasing in $\theta$. This means that there exists a unique marginal investor of cutoff type $\theta_{0}^{*}$ such that $\operatorname{NPV}\left(\theta_{0}^{*}\right)=0$. Combining this with Proposition 1 leads us to the following proposition:

Proposition 2. Asymmetric information creates an energy efficiency gap at the market level. Both social welfare and the number of investing consumers are lower than under perfect information: $W^{A I} \leq W^{P I}$ and $N^{A I} \leq N^{P I} .{ }^{7}$

Anticipation of the quality gap discourages homeowners with low valuations of heating comfort to invest. As a result, investment is suboptimal on both the intensive and extensive margins. Again, without further specification of the technology $E(\cdot, \cdot)$, we cannot conclude about how aggregate energy use differs in the two equilibria.

function under perfect information would also be flat but set at the maximum quality level, which internalizes the effect of quality on energy expenditures.

${ }^{7} N^{*} \equiv 1-F\left(\theta_{0}^{*}\right)$ is the equilibrium number of participants, with $F(\cdot)$ the cumulative distribution function of $\theta . \quad W^{*}$ is aggregate welfare, calculated under zero-profit condition as the sum of utility before investment for non-participants and utility after investment for participants: $W^{*} \equiv \int_{0}^{\theta_{0}^{*}} U^{0}\left(\theta, s_{\theta}^{0}\right) \mathrm{d} F(\theta)+$ $\int_{\theta_{0}^{*}}^{+\infty} U\left(\theta, s_{\theta}^{*}, q_{\theta}^{*}\right) \mathrm{d} F(\theta)$. 


\subsection{Policy solutions}

The textbook remedy to moral hazard is a risk-sharing contract. In the context of home energy retrofits, such a contract can take the form of energy-savings insurance. Alternatively, a regulator may want to address the problem with a verifiable quality standard. A third option, sometimes found in practice, is to combine the two. In this section, we compare the two solutions in their purest form in order to identify their relative strengths and weaknesses. We find that none can achieve the first-best outcome.

Energy-savings contracts and double moral hazard. Energy-savings contracts or insurance, more commonly referred to as energy performance contracts, have been offered for nearly twenty years in the commercial sector (Mills 2003), but less frequently in the residential sector. ${ }^{8}$ Such contracts typically have the contractor pay the homeowner any shortfall in energy savings below a pre-agreed baseline. In our simple framework with no risk-aversion, insurance can be modeled as a contract specifying a share $k$ of energy expenditures borne by the contractor in exchange for an actuarially-fair insurance premium $I$ :

$$
I=k p E(s, q) \Gamma
$$

Such an insurance contract creates an incentive problem which superimposes to the one it is meant to address in the first place. The contract can be modeled as a three-stage game, of which the contractor now is the principal and the homeowner is the agent. In the third stage, the parties cooperatively determine optimal insurance coverage $k$; in the second stage, they privately set their own action, given their belief about insurance coverage $k$ and the other party's action; in the first stage, they decide whether or not to participate.

The insurance induces the contractor to offer some quality, otherwise he would have to make excessive payments to the homeowner. In other words, the risk-sharing contract mitigates supply-side moral hazard. At the limit, it could even eliminate it, as complete coverage $(k=1)$ would induce the contractor to offer socially optimal quality. But at the same time, the contract gives rise to demand-side moral hazard: by lowering the homeowner's marginal value of energy service, it induces her to use more energy. At the limit, complete coverage would drive the homeowner's marginal energy expenditure to zero, thereby inducing her to use energy service up to satiation. Complete coverage is therefore not optimal:

\footnotetext{
${ }^{8}$ GreenHomes America, Inc., NJ-PA Energy Group, LLC. and EcoWatt Energy, LLC. are the few examples we have found of companies offering energy-savings insurance in the U.S. residential sector.
} 
Proposition 3. Energy-savings contracts create demand-side moral hazard. As a consequence, optimal insurance coverage is incomplete $\left(0<k_{\theta}^{*}<1\right)$.

Note that if the building occupant were not adjusting her energy service (e.g., a tenant subscribing to a utility-included rent contract, or an employee in a commercial building), then the second moral hazard would not occur. The optimal contract would stipulate complete coverage and bring the parties to the social optimum. This may explain why energy performance contracts are common in the commercial sector but scarce in the residential one.

Note also that by increasing both $q$ and $s$, the energy-savings contract generates a rebound effect. Unlike that induced by the simple energy efficiency contract discussed in Section 2.2, this rebound effect can be interpreted as moral hazard. ${ }^{9}$

In practice, homeowner types, $\theta$, cannot be observed. A uniform contract with coverage $\bar{k}$ is therefore most likely to be offered to all homeowners. Such a contract generates additional deadweight losses, as the coverage might be optimal to one homeowner, but is suboptimal to all others.

Minimum quality standard. A number of voluntary certifications exist in the marketplace, most notably those provided by the Building Performance Institute (BPI) and the Residential Energy Services Network (RESNET) in the United States. These programs typically ensure that professional workers and contracting companies are trained to the best practices and that their performance is regularly verified.

We model such standards as a verifiable minimum quality input $\bar{q} \cdot{ }^{10}$ The instrument generates two types of inefficiencies. First, compliance needs to be verified, which generates enforcement costs $M(\bar{q})$. These costs do not arise with energy-savings insurance, which rely on a commonly-observed variable, namely, the energy use reported on utility bills. Second, just like a uniform insurance contract, minimum quality standards do not account for consumer heterogeneity.

\footnotetext{
${ }^{9}$ Formally, the rebound effect associated with the energy efficiency contract materializes as the positive slope of the homeowner's reaction function, which is not affected by the informational context. In contrast, the rebound effect associated with the energy-savings contract corresponds to an upward shift of the homeowner's reaction function. This can be interpreted as demand-side moral hazard, just like the downward shift of the contractor's reaction function due to asymmetric information could be interpreted as supply-side moral hazard.

${ }^{10}$ In practice, minimum standards could prescribe the grade of materials installed and the application taken in the installation task.
} 
We show in the Online Appendix that the value of $\bar{q}$ which minimizes the deadweight loss is such that the marginal disutilities of those homeowners for whom the standard is too tight and the marginal utilities (net of marginal enforcement costs) of those willing to invest beyond the standard are equalized.

To sum up, both insurance and standards can mitigate moral hazard, but not eliminate it. Leaving aside the deadweight loss arising from consumer heterogeneity, which is equally faced by a uniform insurance contract and a uniform quality standard, the comparison between the two instruments boils down to how the deadweight loss due to demand-side moral hazard induced by insurance compares with enforcement costs. This is a context-specific question, which we examine numerically in Section 4.

Interaction with energy-use externalities. As we saw earlier, undoing moral hazard has an uncertain effect on energy use due to the rebound effect. To the extent that it backfires while energy-use externalities remain unpriced, implementing policy remedies to moral hazard can have the unintended consequence of exacerbating deadweight losses. In the Online Appendix, we uncover sufficient conditions for this not to occur. In sum, energyuse externalities are important to consider when performing a welfare analysis of policy instruments as they can influence the welfare ordering.

\section{Empirical evidence of supply-side moral hazard}

We now present three empirical facts which together suggest that contractors engage in moral hazard by poorly installing energy efficiency measures when the quality of their work is hard to verify. We do so using a rich dataset from a utility-sponsored retrofit program ran in Florida.

We first find that realized energy savings after retrofit are below predicted savings for several retrofit measures, a puzzle that is increasingly documented but still highly debated (Metcalf and Hassett 1999; Fowlie, Greenstone, and Wolfram 2015). The discrepancy is specifically large for those measures, the quality of which is deemed hard to observe ex post. For other measures, the quality of which is deemed easy to observe, the magnitude and the sign of the gap vary widely. We then find that the discrepancy varies as a function of the day of the week on which a measure was installed and that this variation follows a particular pattern-realized savings are lower toward the end of the week, notably on Fridays, but only for those measures, the quality of which is hard to verify ex post. Lastly, we find that

this Friday effect is not driven by selection. That is, contractors do not choose to install 
particular measures on a specific day of the week (though they might during the weekend). Crucially, prices are not lower on Fridays when realized savings fall.

The second and third empirical facts are a novel contribution to the debate about predictedversus-realized energy savings. Together, they suggest that installation quality is undersupplied on Fridays for measures specifically prone to moral hazard. To explain the Friday effect, we argue that workers are more likely to experience negative productivity shocks toward the end of the workweek and are thus more likely to shrink on quality if the informational context gives them the opportunity to do so.

\subsection{Data}

From 2006 to 2012, Gainesville Regional Utilities (GRU) ran rebate programs for home energy retrofits. The programs targeted a variety of measures, including attic insulation, duct sealing, air-conditioners, pool pumps, refrigerators and windows. Eligibility for rebate required that measures be installed by pre-approved contractors. Prior to completion, each project had to undergo an audit performed by a third party to assess the potential energy savings associated with the measures, based on ex ante engineering calculations. ${ }^{11}$ We restrict our analysis to homes where only one retrofit measure was undertaken.

We consider a sample of 4,099 projects for which the following information is available: type of measure completed, predicted energy savings, rebate amount, price paid to the contractor, and, crucially for our empirical exercise, the date on which a measure was installed. Table 1 provides summary statistics. We match the program data with electricity and natural-gas billing data recorded by GRU between 2002 and 2013. This procedure allows us to link the characteristics of a retrofit measure to its impact on energy use.

\subsection{Empirical strategy}

A first challenge in detecting moral hazard is that quality is not directly observed in our setting. Neither inputs to (e.g., hours worked and skills mobilized by installers, grade of the products and materials installed) nor outputs of the measures (e.g., number and type of defects) are documented. Our strategy to detect changes in quality then relies on estimating realized energy savings, which is strongly correlated with the quality of installation.

\footnotetext{
${ }^{11}$ Engineering estimates of energy savings are measure-specific. They take into account home-specific features (building period, etc.) when necessary, namely for all measures except refrigerators and pool pumps.
} 
Our empirical strategy consists to uncover heterogeneity in realized savings along two dimensions. First, we classify the quality of installation as either easy or hard to observe by the homeowners, and distinguish energy savings for these two categories of measures. We consider a measure hard-to-observe if it meets two criteria: (i) the installation is an arduous task that requires significant labor input and (ii) the quality of installation is difficult to verify by a non-expert. Attic insulation and duct sealing, which both require significant installation work and can hardly be verified after completion, belong to this category. Other retrofit measures that mostly consist of replacing equipment, such as air-conditioners, pool pumps or refrigerators, are deemed easy to observe. Window replacement, which requires significant labor input but leaves few features hidden, could fall in either category. In our preferred specification, we classify it as easy-to-observe. In a robustness check, we move it into the hard-to-observe category and find little impact.

Second, we allow for heterogeneity in the estimates using interactions with day-of-the-week dummies. We hypothesize that worker's productivity is subject to systematic variations over the week which are unaccounted for in the retrofit contract. In particular, we expect output to be lower toward the end of the week, namely on Fridays and during weekends. The motivation comes from labor studies showing that productivity tends to be lower on Fridays, especially in the construction sector (e.g., Bryson and Forth, 2007). Workers' fatigue is the reason most frequently invoked. ${ }^{12}$ We then compare day-of-the-week estimates between easy and hard-to-observe measures. Our testable hypotheses is that hard-to-observe measures deliver fewer energy savings if they have been completed at the end of the workweek, but that easy-to-observe measures are not subject to such a day-of-the-week effect.

We estimate realized energy savings using a difference-in-differences estimator where the estimate can vary with respect to the two categories of measure and the day of completion. The estimation follows the quasi-experimental approach of Fowlie, Greenstone, and Wolfram (2015),Zivin and Novan (2016), and Maher (2016), only extended with interactions with dayof-the-week dummies, $D W$, and dummies that identify hard-to-observe and easy-to-observe measures, noted HTO and ETO, respectively. We consider the following regression model:

\footnotetext{
${ }^{12}$ Other explanations include: staff shortage, e.g., workers calling out "sick" on Friday; quit-time, e.g., workers leaving early to start weekend; backlog, e.g., workers rushing to finish job to avoid having to revisit site on weekend/next week.
} 
$\log \left(k W h_{i t}\right)=\alpha H T O_{i t}+\gamma E T O_{i t}+\sum_{d}^{D-1} \alpha_{d} \cdot D W_{i d} \cdot H T O_{i t}+\sum_{1}^{n-1} \gamma_{d} \cdot D W_{i d} \cdot E T O_{i t}+\lambda_{i m}+\alpha_{t}+\epsilon_{i t}$,

where the dependent variable is the logarithm of the total monthly energy use (electricity plus natural gas) of a particular household. The dummy $H T O_{i t}$ turns from zero to one the month household $i$ invests in a hard-to-observe retrofit measure. The dummy ETO $O_{i t}$ is defined similarly for investments in easy-to-observe measures. The terms $\lambda_{i m}$ and $\alpha_{t}$ denote household-calendar month fixed effects and month-of-sample fixed effects, respectively, and implement the difference-in-differences estimator to estimate energy savings. Finally, $D W_{i d}$ is a dummy that identifies a specific day (or period) of the week $d$ and estimates heterogeneity in average realized energy savings with respect to the day of completion. Each dummy takes a value of one if household $i$ got the measure completed on day $d$ and zero otherwise. For instance, "Friday" effects are estimated by having a dummy, $D W_{i F r i d a y}$, that turns on if the measure was completed on a Friday; the omitted dummy corresponds to the remaining days of the week (Monday to Thursday). The coefficient $\alpha_{d}$ estimates the specific effect of day $d$ on realized energy savings for hard-to-observe measures; we expect it to be positive if moral hazard exists. Coefficient $\gamma_{d}$ estimates the same effect for easy-to-observe measures. This is essentially a placebo test-we expect the coefficient to be zero.

\subsection{Identification}

The validity of the difference-in-differences estimator is guaranteed by two sets of fixed effects. The dummies $\lambda_{i m}$ captures all household-specific characteristics that influence energy use. Note that we allow for variation by calendar month $m$, which captures any seasonal pattern in household-specific energy usage. Exploiting several years of monthly consumption allows us to identify the coefficients $\lambda_{i m}$. The month $t$-of-sample fixed effects $\left(\alpha_{t}\right)$ control for weather and any other contemporaneous shocks that may affect monthly consumption. Our large sample of retrofits allows us to identify the coefficients $\alpha_{t}$. We thus effectively assume that conditional on $\lambda_{i m}$ and $\alpha_{t}$, households were subject to similar trends in energy usage prior to the retrofit measure. By the end of our time horizon, all households are treated.

The estimation is restricted to the sample of single-measure retrofit projects, which leads us to exclude projects that combine several measures, such as low-income programs and whole-home performance. The restriction ensures that we focus on households that had only one interaction with the contractors, which facilitates how we classify a project as easy or 
hard to observe. We further restrict the sample to projects that cost under $\$ 10,000$. The reasoning is that excluded projects are likely to take more than one day. ${ }^{13}$ Ultimately, the working sample contains 4,099 projects, including 1,026 hard-to-observe measures and 3,073 easy-to-observe ones.

The validity of the test for moral hazard relies on the assumption that contractors do not select the day of the week on which they complete a particular measure. Such selection can be directly tested by comparing projects along key dimensions using observable attributes of the retrofit contracts. Table 2 compares the average retrofit prices, average predicted energy savings, average rebate amounts, and number of retrofit performed across day (or period) of completion. For all four variables, we observe no statistically significant difference during the days of the workweek. Importantly for our identification, Friday jobs are of the same size as other jobs, as measured by both their price and predicted energy savings; any difference in realized energy savings is therefore due to other factors. In contrast, weekend projects, which happen to be very few, do exhibit some differences. This suggests that selection might be at play during the weekend, which leads us to treat weekends separately in the estimation. ${ }^{14}$

\subsection{Results}

Columns 2 and 3 of Table 1 replicate the findings of Maher (2016). Most retrofit measures subsidized by GRU exhibit a discrepancy between predicted and realized savings. For the two main retrofit measures classified as hard-to-observe, attic insulation and duct repair, realized savings are $60 \%$ and $32 \%$, respectively, of predicted savings. ${ }^{15}$ For easy-to-observe measures, the discrepancy varies widely in magnitude but also in sign. For three out of seven of them, realized savings are indeed well above predicted ones.

Regression results that account for heterogeneity with respect to the day-of-the-week and observability of the measure (Equation 5) are displayed in Table 3. Each column corresponds to a specification that identifies a specific day-of-the-week effect on energy savings. The interaction terms are the additional savings for the day identified. For instance, for the model that estimates the Friday effect (column V), the coefficient represents the additional

\footnotetext{
${ }^{13}$ The data do not allow us to ascertain that completion of single measures takes exactly one day, that is, less than eight hours. We nevertheless think this is a reasonable assumption for the technologies considered.

${ }^{14}$ The problem could come from the way contractors either favor certain projects or elect to work during the weekend.

${ }^{15}$ The estimate of realized saving for duct repair is not statistically different from zero, while predicted saving are $107.5 \mathrm{kWh} /$ month.
} 
savings relative to the average savings for Monday to Thursday. A positive estimates means that realized savings on that particular day are lower than for other days of installation.

For measures classified as hard-to-observe, we find a positive, economically large and statistically significant Friday effect, but we do not find any such effect for other days of the workweek. All models include an interaction for weekend effect, which is always positive but not statistically significant. This effect is still present if we group Friday and weekend estimates together (column VI). The magnitude of the estimates, obtained by adding the coefficients $H T O$ and $H T O \cdot D H_{\text {Friday }}$ imply that the realized energy savings for hard-toobserve measures completed at the end of the week are close to zero and not statistically significant. For other days of the week, the savings are of the expected sign, economically large and statistically significant. Importantly, the Friday-effect only holds for hard-toobserve measures. For easy-to-observe measures, we do observe large savings on each workday and slightly larger savings on Wednesdays.

The magnitude of the Friday effect is large. Table 4 displays estimates of the realized savings with and without controls for the Friday effect, and compares them to the predicted savings. After controlling for the Friday effect, the discrepancy between predicted and realized energy savings shrinks by $65 \%$ for hard-to-observe retrofit measures. It remains unaffected for easy-to-observe measures, regardless of the controls (Table 7, Appendix).

These results are robust to a number of specification tests presented in the Appendix. Excluding low-income weatherization and home performance projects have little impact. ${ }^{16}$ Performing the estimation in level instead of logarithm still produces a positive Friday effect for hard-to-observe measures. The coefficient is, however, marginally statistically significant. $^{17}$

Altogether, the results give support to our hypothesis that under-treatment occurs on Fridays when quality is hard to verify. Though essentially a positive test of existence of moral hazard, our analysis additionally indicates that the problem is important, perhaps enough to undo all energy savings.

\footnotetext{
${ }^{16}$ Classifying windows replacement as a hard-to-observe measure does not qualitatively change the results either.

${ }^{17}$ The difference in the Friday effect for easy versus hard-to-observe measures has a $p$-value of 0.0793.
} 


\section{A numerical illustration}

We now specify and parameterize the model developed in Section 2 to quantify the energy efficiency gap due to moral hazard and compare policy solutions in the presence of energyuse externalities. Our numerical exercise focusses on attic insulation, which is frequently advocated as the most cost-effective measure to reduce energy use in the residential sector. Parameterization relies on the GRU program data, results from the econometric analysis conducted in the previous section, and the U.S. Residential Energy Consumption Survey (RECS).

\subsection{Model specifications}

Supply side. The impact of quality on energy use is modeled with the following functional form:

$$
E(s, q) \equiv\left(1-G_{\min }-\left(G_{\max }-G_{\min }\right)\left(1-\mathrm{e}^{-\omega q}\right)\right) E^{0}(s),
$$

where the quality of installation $q$ is assumed to be dimensionless and ranging from $0 \%$ to $100 \%$. Parameters $G_{\min }$ and $G_{\max }$ capture the minimum and maximum efficiency improvement that the investment can deliver, respectively. We set these values to $1 \%$ and $15 \%$ based on the range of predicted energy savings estimated in the GRU program. Parameter $\omega$ captures the sensitivity of the reduction in energy use with respect to the level of quality provided. We set $\omega$ so that the efficiency evaluated at $q=95 \%$ is the 95 th percentile of the efficiency estimated for attic insulation in Section 3 (12.6\%).

The cost of supplying quality is specified as follows:

$$
C(q) \equiv K+\frac{\phi}{2} q^{2}
$$

with $K>0$ and $\phi>0$. These parameters are calibrated using two moments derived from the GRU data so that (i) the equilibrium quality under perfect information generates the 95th percentile of the predicted energy savings estimated for attic insulation in Section 3 $(7.5 \%)$ and (ii) the cost of this equilibrium quality matches the median cost estimate, $\$ 678$.

Demand side. The homeowner's utility and energy use are specified with the following functional forms:

$$
V(s) \equiv V_{\max }\left(1-\mathrm{e}^{-\alpha\left(s-s_{\min }\right)}\right)
$$




$$
E^{0}(s) \equiv \beta\left(s-s_{\min }\right)^{\gamma},
$$

with $\alpha>0, \beta>0$ and $\gamma>1$. Both functions vary with indoor temperature $s$. They are parameterized using information on indoor temperature, energy use, energy expenditure and income contained in the RECS online database for 2009. We extract a preliminary sample of 4,306 U.S. households who own and occupy their house and pay for natural gas for space heating. We then remove households who declare a winter daytime temperature below $60^{\circ} \mathrm{F}$ or above $80^{\circ} \mathrm{F}$ and thereby obtain a working sample of 4,266 households. ${ }^{18}$ This sample covers $35 \%$ of the complete dataset.

Calibration of the parameters relies on moments derived for the median homeowner, assumed to be of type $\theta=1$. It proceeds as follows:

- The maximum value derived from space heating, $V_{\max }$, is set equal to $\$ 2,816$. This value is obtained by assuming that $4.3 \%$ of the annual median income $(\$ 65,000)$ is used for space heating. This fraction corresponds to the 95th percentile of the income share dedicated to space heating in the RECS sample.

- Parameters $\alpha, \beta$ and $\gamma$ are calibrated so that: (i) the optimal temperature to the median homeowner is $69^{\circ} \mathrm{F}$, the median of the RECS sample; (ii) at this temperature, the median homeowner's annual use of natural gas for space heating is $50 \mathrm{MCF}$, the median of the RECS dataset; (iii) the price-elasticity of energy use evaluated at $s=69^{\circ} \mathrm{F}$ is -0.4 , the middle value of the range found in the literature by Gillingham, Newell, and Palmer (2009) for short-term price-elasticities of natural gas use $([-0.03 ;-0.76])$.

- Non-energy attributes $\epsilon$ are calibrated so that the median homeowner is the marginal participant. ${ }^{19}$ That is, she is indifferent between not investing and investing under asymmetric information: $N P V^{A I}(\theta=1)=0$. This leads to non-energy net benefits of $\$ 441$.

\footnotetext{
${ }^{18}$ We set thus set $s_{\min }=60^{\circ} \mathrm{F} \leq s \leq 80^{\circ} \mathrm{F}$.

${ }^{19}$ Participation is therefore set to $50 \%$ under asymmetric information. In the RECS sample, the annual fraction of homeowners investing in insulation is $3.4 \%$ (6.8\% of the population declare having insulation installed in the last two years), a rate close to $2.9 \%$, which would be the annual rate if investment occurred once every 35 years. Therefore, a participation of $100 \%$ in our model can be interpreted as an annual insulation rate of $6.8 \%$ in the population.
} 
The price of energy $p$ is set equal to $\$ 10.5$ per thousand cubic feet $(\mathrm{MCF})$, which is the variable part of the GRU residential rates for natural gas in 2015. This is close to the average price paid for natural gas use for space heating in the RECS dataset $(\$ 11.14 / \mathrm{MCF})$ and the $\$ 11.45 / \mathrm{MCF}$ reported by Davis and Muehlegger (2010). The discount rate $r$ is set equal to $7 \%$, the value recommended by the U.S. Office of Management and Budget (OMB 2009) to assess private investment. The investment horizon is set equal to 35 years, the conventional lifetime of attic insulation

Finally, to model heterogeneity in $\theta$, the distribution of temperatures observed in the RECS sample (mean $69.0^{\circ} \mathrm{F}$, standard deviation $3.4^{\circ} \mathrm{F}$ ) is fitted with a log-normal distribution of homeowners' types $\theta$ with parameters $\mu=0$ and $\sigma=1$ (see Figure 1).

Energy-use externalities. As we saw in Section 2, the comparison of policy solutions to moral hazard will be affected by energy-use externalities. In our policy scenarios, we assume that the externalities associated with natural gas are valued at $\$ 1.69 / \mathrm{MCF}$, reflecting a social value of carbon of $\$ 33 / \mathrm{tCO}_{2}$.

\subsection{Quantification of the energy efficiency gap}

Figure 3 maps different equilibra in the framework proposed by Jaffe, Newell and Stavins ${ }^{20}$ (1994), so as to visualize the trade-offs between economic efficiency (measured as present discounted welfare) and energy efficiency. In Jaffe and Stavins' words, the perfect-information equilibrium with unpriced externalities corresponds to the "Narrow economists' optimum." Further improvements along both the energy efficiency and welfare dimensions can occur if externalities are internalized through a Pigouvian price, establishing the "True social optimum". The welfare gains from undoing moral hazard (\$507) are 2.4 times larger than those from internalizing energy-use externalities $(\$ 210)$. The difference is in part due to the small size of the marginal externality, $\$ 1.69 / \mathrm{MCF}$, relative to the price of energy, $\$ 10.50 / \mathrm{MCF}$, which approximates the marginal loss due to inefficient investment under moral hazard. ${ }^{21}$

Sensitivity analysis. The key parameters of the model are varied according to assumptions outlined in Table 5. Scenario variants are meant to mimic different barriers to energy

\footnotetext{
${ }^{20}$ This is the ultimate version of a diagram which first appeared in .

${ }^{21}$ The moral-hazard market failure can also be restated as an average implied discount rate of $18 \%$. This value is computed by solving and averaging the $\theta$-specific discount rates that match the quality offered under perfect information with the net present value enjoyed by the homeowner under asymmetric information, discounted at $7 \%$ by assumption. It is consistent with the estimates reported in the empirical literature on energy efficiency investments ().
} 
efficiency, which, according to the taxonomy referred to in the introduction, are categorized either as market failures, nonmarket failures or behavioral anomalies. Figure 4 displays the size of the deadweight losses due to moral hazard across scenarios together with the elasticity of the deadweight loss with respect to each parameter.

Parameterization of the efficiency function is the most sensitive determinant of the deadweight loss. This underlines the importance of reducing errors in the measurement of technology efficiency to perform accurate welfare analysis of energy efficiency programs. The extent of distortions in energy markets and in the capitalization of energy savings are the next important determinants. This illustrates the importance of potential interactions between market failures. In contrast, under-valuation of energy savings and errors in the measurement of technology cost have little impact. Lastly, the parameters of homeowners' utility have no influence, a result we formalize below.

The relative magnitude of moral hazard and externalities varies widely, from around 10:1 in the "High efficiency" scenario to around 1:3 in the "High discount rate" scenario. This wide range of variation stresses the critical aspect of parameterization, but nonetheless suggests that moral hazard deserves at least as much consideration as externalities.

A sufficient statistic of the deadweight loss. To formalize parameter sensitivity, we show in the Online Appendix that the deadweight loss can be approximated by the following sufficient statistic:

$$
\overline{\Delta W}=-\left.p \Delta E\right|_{s} \Gamma(r, l)-\Delta C
$$

The formula weighs the cost of quality against its benefits in terms of gross energy savings. This corresponds to a net present value calculation that only takes into account technological information. It does not require knowledge of the utility function $V(\cdot)$ nor the effect of the energy service $s$ on energy use $E(\cdot, \cdot)$. This explains why parameters $V_{\max }$ and $\sigma$ are found to have no influence on the deadweight loss. It also means that the direct rebound effect can be ignored. Still, the formula contains the key parameters of the market and behavioral environment $p, l$ and $r$. In our simulations, we find that it never underestimates the exact deadweight loss by more than $7 \%$ across scenarios. 


\subsection{Insurance versus standard}

Figure 3 displays the welfare effects of energy-savings insurance and minimum quality standards, with and without externalities. Optimal insurance contracts, which are homeownerspecific, have an average coverage of $18 \%$. Since homeowner types may not be perfectly observable, it is worth also considering uniform insurance contracts. As depicted in the figure, incremental coverage initially improves both energy efficiency and welfare, up to a point where efficiency becomes so expensive that it starts deterring participation, hence a backward bend in both efficiency and welfare trajectories. The best such contract is located farthest to the right of the horizontal axis. Absent externalities, the associated coverage is $22 \%$. Otherwise, coverage is $10 \%$. The welfare gains with the best uniform insurance are only slightly below those provided by optimal homeowner-specific contracts. This means that in the context considered here, ignoring consumer heterogeneity in policy design has little implication. The point also applies to standards. Just like uniform insurance, minimum quality standards draw an ellipse driven by increasing stringency. The best standard mandates a quality of $43 \%$ if externalities are absent and $49 \%$ otherwise. Anyway, it brings market agents very close to the social optimum.

Overall, insurance mitigates almost half of the deadweight loss due to moral hazard if externalities are absent, but it has little effect otherwise. The best standard appears substantially more efficient in the figure. Yet unlike insurance, standards require verification, monitoring and enforcement. In practice, this would require an audit post-installation. As reported by Palmer, Walls, Gordon, and Gerarden (2013), the cost of an audit for retrofits is on average $\$ 347$ in the United States. Accounting for this as enforcement cost, the net effect of the best standard vanishes and policy comparison is more ambiguous.

An important takeaway is that unlike that of insurance, the performance of standards is relatively unaffected by energy-use externalities. This is due to the nature of the rebound effect induced by each instrument. Both policies induce a direct rebound effect, as they increase energy efficiency and thus lower the marginal cost of energy services. In addition, insurance coverage further reduces marginal energy expenditures. This causes demand-side moral hazard - an over-use of energy which exacerbates externalities. Failure to internalize energy-use externalities thus favors minimum quality standard over energy-savings insurance. 


\section{Conclusion}

Many energy efficiency measures can be thought of as credence goods, the performance of which is never fully revealed to the buyer. This characteristic is conducive to a variety of information asymmetries which can cause under-investment in energy efficiency, a phenomenon known as the energy efficiency gap. In this paper, we were interested in the existence of and solutions to moral hazard in the quality of installation of energy efficiency measures.

We provide empirical evidence of this market failure in the U.S. home retrofit market. Using data from a utility-sponsored retrofit program ran in Florida, we find that for measures such as attic insulation and duct sealing, the quality of which is hard to observe ex post, energy savings are significantly lower when the retrofit was completed on a Friday - a day particularly prone to negative shocks on workers' productivity - than on any other weekday. We interpret this outcome as supply-side moral hazard and show that it can explain a large fraction of the discrepancy between predicted and realized energy savings, an increasingly documented manifestation of the energy efficiency gap. In theory, the problem can be addressed by private interventions such as energy-savings insurance or public interventions such as minimum quality standards. We show that neither intervention can eliminate the loss: insurance induce demand-side moral hazard, as lower marginal expenditures encourage over-use of energy; standards incur enforcement costs. The comparison between the two is therefore context-specific. Our numerical model suggests that while energy-savings contracts with small insurance coverage (typically 10-20\%) can significantly mitigate the moral hazard, they also amplify energy-use externalities. Minimum quality standards therefore seem more desirable if externalities are left unpriced.

We see several interesting extensions to our analysis. On the theoretical front, attention should be focused on reputation strategies. The finding that energy efficiency providers do offer some quality during most of the workweek suggests the incentive might be important. On the empirical front, new experiments allowing for direct observation of quality should be designed, in order to directly investigate the link between installation defects and missing energy savings. On the policy front, efforts should be devoted to ex post evaluation of energy performance contracts, quality certifications and other existing remedies to moral hazard. 


\section{Acknowledgements}

The authors started this research at the Precourt Energy Efficiency Center (PEEC), Stanford University. We thank PEEC for funding and James Sweeney for encouragements and comments. We are grateful to Tiger Adolf, Rick Diamond, Matt Golden, Evan Mills and Carol Zabin for early discussions that motivated this work. We thank Philippe Bontems, Frédéric Branger, Lawrence Goulder, Christian Huse, Franck Lecocq, Marie-Laure Nauleau, Philippe Quirion, and Adrien Vogt-Schilb for comments on earlier drafts. Lastly, we thank participants to the various seminars and conferences where the paper was presented for their feedback. 


\section{References}

Abbring, J. H., J. J. Heckman, P.-A. Chiappori, and J. Pinquet (2003): "Adverse Selection and Moral Hazard in Insurance: Can Dynamic Data Help to Distinguish?," Journal of the European Economic Association, 1(2-3), 512-521.

Allcott, H., and M. Greenstone (2012): "Is There an Energy Efficiency Gap?," Journal of Economic Perspectives, 26(1), 3-28.

Allcott, H., S. Mullainathan, and D. Taubinsky (2014): "Energy policy with externalities and internalities," Journal of Public Economics, 112, 72-88.

Balafoutas, L., A. Beck, R. Kerschbamer, and M. Sutter (2013): "What Drives Taxi Drivers? A Field Experiment on Fraud in a Market for Credence Goods," The Review of Economic Studies, 80(3), 876-891.

Brounen, D., And N. KoK (2011): "On the economics of energy labels in the housing market," Journal of Environmental Economics and Management, 62(2), 166-179.

Bryson, A., And J. Forth (2007): "Are There Day of the Week Productivity Effects?," Discussion paper, Manpower Human Resources Lab.

Campolieti, M., and D. E. Hyatt (2006): "Further Evidence on the "Monday Effect" in Workers' Compensation," Industrial \& Labor Relations Review, 59(3), 438-450.

Cooper, R., And T. W. Ross (1985): "Product Warranties and Double Moral Hazard," The RAND Journal of Economics, 16(1), 103-113.

Davis, L. W. (2012): "Evaluating the Slow Adoption of Energy Efficient Investments: Are Renters Less Likely to Have Energy Efficient Appliances?," in The Design and Implementation of U.S. Climate Policy, ed. by D. Fullerton, and C. Wolfram, pp. 301-316. University of Chicago Press.

Davis, L. W., A. Fuchs, And P. Gertler (2014): "Cash for coolers: evaluating a largescale appliance replacement program in Mexico," American Economic Journal: Economic Policy, 6(4), 207-238.

Davis, L. W., And E. Muehlegger (2010): "Do Americans consume too little natural gas? An empirical test of marginal cost pricing," The RAND Journal of Economics, 41(4), 791-810.

DE WiLde, P. (2014): "The gap between predicted and measured energy performance of buildings: A framework for investigation," Automation in Construction, 41, 40-49. 
Dulleck, U., And R. Kerschbamer (2006): "On Doctors, Mechanics, and Computer Specialists: The Economics of Credence Goods," Journal of Economic Literature, 44(1), $5-42$.

Dulleck, U., R. Kerschbamer, and M. Sutter (2011): "The Economics of Credence Goods: An Experiment on the Role of Liability, Verifiability, Reputation, and Competition," American Economic Review, 101(2), 526-555.

Fowlie, M., M. Greenstone, and C. Wolfram (2015): "Do Energy Efficiency Investments Deliver? Evidence from the Weatherization Assistance Program," Working Paper 21331, National Bureau of Economic Research.

Fuerst, F., P. McAllister, A. Nanda, and P. Wyatt (2015): "Does energy efficiency matter to home-buyers? An investigation of EPC ratings and transaction prices in England," Energy Economics, 48, 145-156.

Gillingham, K., M. Harding, and D. Rapson (2012): "Split Incentives in Residential Energy Consumption," The Energy journal, 33(2), 37-62.

Gillingham, K., R. G. Newell, and K. Palmer (2009): "Energy Efficiency Economics and Policy," Annual Review of Resource Economics, 1(1), 597-620.

Gillingham, K., And K. Palmer (2014): "Bridging the Energy Efficiency Gap: Policy Insights from Economic Theory and Empirical Evidence," Review of Environmental Economics and Policy, p. ret021.

Houde, S., And J. E. Aldy (2014): "Belt and Suspenders and More: The Incremental Impact of Energy Efficiency Subsidies in the Presence of Existing Policy Instruments," Discussion paper, National Bureau of Economic Research.

Jaffe, A. B., And R. N. Stavins (1994): "The energy-efficiency gap: What does it mean?," Energy Policy, 22(10), 804-810.

Krishnamurthy, C. K. B., and B. Kriström (2015): "How large is the Owner-Renter Divide in Energy Efficient Technology? Evidence from an OECD cross-section," The Energy Journal, 36(4).

Levinson, A., and S. Niemann (2004): "Energy use by apartment tenants when landlords pay for utilities," Resource and Energy Economics, 26(1), 51-75.

Maher, J. (2016): "Measuring the Accuracy of Engineering Models in Predicting Energy Savings from Home Retrofits: Evidence from Monthly Billing Data," Working paper. 
Maruejols, L., And D. Young (2011): "Split incentives and energy efficiency in Canadian multi-family dwellings," Energy Policy, 39(6), 3655-3668.

Metcalf, G. E., and K. A. Hassett (1999): "Measuring the Energy Savings from Home Improvement Investments: Evidence from Monthly Billing Data," Review of Economics and Statistics, 81(3), 516-528.

Mills, E. (2003): "Risk transfer via energy-savings insurance," Energy Policy, 31(3), 273281.

Murphy, L. (2014): "The influence of energy audits on the energy efficiency investments of private owner-occupied households in the Netherlands," Energy Policy, 65, 398-407.

Myers, E. (2013): “Asymmetric Information in Residential Rental Markets: Implications for the Energy Efficiency Gap," EI @ Haas WP 246.

OMB, U. S. O. O. M. A. B. (2009): "Informing regulatory decisions: report to Congress on the costs and benefits of federal regulations and unfunded mandates on state, local, and tribal entities.," Discussion Paper Appendix D, OMB Circular A-4.

Palmer, K., M. Walls, H. Gordon, and T. Gerarden (2013): "Assessing the energyefficiency information gap: results from a survey of home energy auditors," Energy Efficiency, 6(2), 271-292.

SchneIder, H. S. (2012): "Agency Problems and Reputation in Expert Services: Evidence from Auto Repair," The Journal of Industrial Economics, 60(3), 406-433.

ScotT, S. (1997): "Household energy efficiency in Ireland: A replication study of ownership of energy saving items," Energy Economics, 19(2), 187-208.

Sorrell, S. (2004): "Understanding barriers to energy efficiency," in The Economics of Energy Efficiency: Barriers to Cost-Effective Investment, ed. by S. Sorrell, E. O'Malley, J. Schleich, and S. Scott, pp. 25-93. Edward Elgar, Cheltenham.

SunikKa-Blank, M., And R. Galvin (2012): "Introducing the prebound effect: the gap between performance and actual energy consumption," Building Research $\&$ Information, 40(3), 260-273.

Zabin, C., T. W. Lester, And J. Halpern-Finnerty (2011): "Chapter Four: Case studies of the HVAC, residential retrofit, and commercial lighting control sectors," in California workforce education and training needs assessment: for energy efficiency, distributed generation, and demand response, pp. 89-118. Institue for Research on Labor and Employment, University of California, Berkeley. 
Zivin, J. G., And K. Novan (2016): "Upgrading Efficiency and Behavior: Electricity Savings from Residential Weatherization Programs," The Energy Journal, 37(4). 
TABLE 1. Summary statistics by energy efficiency measure

\begin{tabular}{|c|c|c|c|c|c|c|c|c|}
\hline & $\begin{array}{c}\text { Predicted } \\
\text { energy savings } \\
\text { (MWh/year) } \\
\text { mean (SD) }\end{array}$ & $\begin{array}{c}\text { Predicted } \\
\text { energy savings } \\
(\mathrm{kWh} / \text { month) } \\
\text { mean }(\mathrm{SD})\end{array}$ & $\begin{array}{c}\text { Maher (2016)'s DiD } \\
\text { energy savings } \\
\text { (kWh/month) } \\
\text { coefficient (SE) }\end{array}$ & $\begin{array}{c}\text { Project } \\
\text { price } \\
\text { mean (SD) }\end{array}$ & $\begin{array}{c}\text { Rebate } \\
\text { amount } \\
\text { mean (SD) }\end{array}$ & $\begin{array}{c}\text { Day of } \\
\text { completion }\end{array}$ & Observability & \# Obs. \\
\hline Attic Insulation & $\begin{array}{c}1.55 \\
(0.04)\end{array}$ & $\begin{array}{l}129.17 \\
(3.33)\end{array}$ & $\begin{array}{c}78.65^{* * *} \\
(26.91)\end{array}$ & $\begin{array}{c}\$ 761 \\
(\$ 501)\end{array}$ & $\begin{array}{r}\$ 199 \\
(\$ 77)\end{array}$ & Wednesday & Hard & 575 \\
\hline Duct Repair & $\begin{array}{c}1.29 \\
(0.08)\end{array}$ & $\begin{array}{l}107.50 \\
(6.67)\end{array}$ & $\begin{array}{c}33.72 \\
(33.77)\end{array}$ & $\begin{array}{c}\$ 863 \\
(\$ 911)\end{array}$ & $\begin{array}{l}\$ 360 \\
(\$ 99)\end{array}$ & Wednesday & Hard & 367 \\
\hline $\begin{array}{l}\text { Low-Interest } \\
\text { Loan }\end{array}$ & $\begin{array}{l}- \\
-\end{array}$ & $\begin{array}{l}- \\
-\end{array}$ & $\begin{array}{c}73.04 \\
(79.79)\end{array}$ & - & $\begin{array}{l}\$ 1,089 \\
(\$ 505)\end{array}$ & Wednesday & Hard & 84 \\
\hline $\begin{array}{l}\text { Super-SEER } \\
\text { Central AC }\end{array}$ & $\begin{array}{c}1.93 \\
(0.53)\end{array}$ & $\begin{array}{l}160.83 \\
(44.17)\end{array}$ & $\begin{array}{c}208.9^{* * *} \\
(27.11)\end{array}$ & $\begin{array}{c}\$ 7,291 \\
(\$ 1,467)\end{array}$ & $\begin{array}{l}\$ 555 \\
(\$ 62)\end{array}$ & Wednesday & Easy & 623 \\
\hline $\begin{array}{l}\text { SEER-15 } \\
\text { Central AC }\end{array}$ & $\begin{array}{c}0.55 \\
(0.12)\end{array}$ & $\begin{array}{c}45.83 \\
(10.00)\end{array}$ & $\begin{array}{c}161.3^{* * *} \\
(37.60)\end{array}$ & $\begin{array}{c}\$ 5,672 \\
(\$ 1,412)\end{array}$ & $\begin{array}{l}\$ 295 \\
(\$ 44)\end{array}$ & Wednesday & Easy & 297 \\
\hline Pool Pump & $\begin{array}{c}1.76 \\
(0.16)\end{array}$ & $\begin{array}{l}146.67 \\
(13.33)\end{array}$ & $\begin{array}{l}101.6^{* *} \\
(47.05)\end{array}$ & $\begin{array}{l}\$ 1,452 \\
(\$ 505)\end{array}$ & $\begin{array}{l}\$ 284 \\
(\$ 97)\end{array}$ & Wednesday & Easy & 394 \\
\hline $\begin{array}{l}\text { Refrigerator } \\
\text { Removal }\end{array}$ & $\begin{array}{c}1.53 \\
(0.40)\end{array}$ & $\begin{array}{l}127.50 \\
(33.33)\end{array}$ & $\begin{array}{c}47.57^{* * *} \\
(17.47)\end{array}$ & $\begin{array}{l}- \\
-\end{array}$ & $\begin{array}{c}\$ 72 \\
(\$ 12)\end{array}$ & Wednesday & Easy & 1,162 \\
\hline $\begin{array}{l}\text { Low-Income } \\
\text { Grant }\end{array}$ & $\begin{array}{c}1.12 \\
(0.82)\end{array}$ & $\begin{array}{c}93.33 \\
(68.33)\end{array}$ & $\begin{array}{c}52.87 \\
(38.52)\end{array}$ & $\begin{array}{c}\$ 301 \\
(\$ 339)\end{array}$ & $\begin{array}{c}\$ 2,170 \\
(\$ 1,528)\end{array}$ & Wednesday & Easy & 227 \\
\hline $\begin{array}{l}\text { Whole Home } \\
\text { Performance }\end{array}$ & $\begin{array}{c}2.49 \\
(1.00)\end{array}$ & $\begin{array}{l}207.50 \\
(83.33)\end{array}$ & $\begin{array}{c}131.1^{* * *} \\
(43.88)\end{array}$ & $\begin{array}{c}\$ 654 \\
(\$ 239)\end{array}$ & $\begin{array}{c}\$ 967 \\
(\$ 289)\end{array}$ & Wednesday & Easy & 342 \\
\hline Low-E Window & $\begin{array}{c}0.66 \\
(0.36)\end{array}$ & $\begin{array}{c}55.00 \\
(30.00)\end{array}$ & $\begin{array}{l}155.2^{* *} \\
(72.66)\end{array}$ & $\begin{array}{c}\$ 3,511 \\
(\$ 2,205)\end{array}$ & $\begin{array}{l}\$ 159 \\
(\$ 81)\end{array}$ & Wednesday & Easy & 28 \\
\hline Total & & & & & & & & 4,099 \\
\hline
\end{tabular}

Notes: The estimates in the column labelled "Maher (2016)'s DiD" are technology-specific estimates of energy savings taken directly from Maher (2016). They are computed using a difference-in-differences estimator similar to that used to estimate the savings with day-of-the-week effects. The regression model does not consider heterogeneity with respect to the day of installation and estimates average savings for each measure. Standard errors are clustered at the household level $(* p<.10 * * p<.05 * * *$ $p<.01)$. The column "Observability" classifies the quality of a measure as "Easy" or "Hard" to observe ex post. 
TABLE 2. Summary statistics by day of the week

\begin{tabular}{|c|c|c|c|c|c|c|c|c|}
\hline & Monday & Tuesday & Wednesday & Thursday & Friday & Weekend & All Days & \# Obs. \\
\hline \multicolumn{9}{|c|}{ A. Predicted energy savings (MWh per year) } \\
\hline \multirow[t]{2}{*}{ HTO measures } & 1.38 & 1.28 & 1.14 & 1.06 & 1.34 & 1.33 & 1.25 & 943 \\
\hline & $(.43)$ & $(.63)$ & $(.82)$ & $(.91)$ & $(.5)$ & $(.67)$ & $(0.69)$ & \\
\hline \multirow[t]{2}{*}{ ETO measures } & 1.57 & 1.55 & 1.59 & 1.45 & 1.55 & 1.41 & 1.54 & 2,801 \\
\hline & $(.65)$ & $(.59)$ & $(.58)$ & $(.71)$ & $(.71)$ & $(.62)$ & $(0.64)$ & \\
\hline \multicolumn{9}{|c|}{ B. Project price (dollars) } \\
\hline \multirow[t]{2}{*}{ HTO measures } & 777 & 791 & 760 & 621 & 770 & 603 & 728 & 734 \\
\hline & $(654)$ & $(776)$ & $(1,002)$ & $(544)$ & $(669)$ & $(619)$ & $(738)$ & \\
\hline \multirow[t]{2}{*}{ ETO measures } & 2,973 & 1,567 & 1,355 & 2,988 & 3,040 & 895 & 2,003 & 1,060 \\
\hline & $(3,271)$ & $(2,720)$ & $(2,660)$ & $(3,252)$ & $(3,211)$ & $(1,974)$ & $(2,976)$ & \\
\hline \multicolumn{9}{|c|}{ C. Rebate amount (dollars) } \\
\hline \multirow[t]{2}{*}{ HTO measures } & 286 & 335 & 373 & 413 & 295 & 254 & 329 & 1,026 \\
\hline & $(181)$ & $(250)$ & $(369)$ & $(375)$ & $(243)$ & $(236)$ & $(291)$ & \\
\hline \multirow[t]{2}{*}{ ETO measures } & 622 & 404 & 351 & 632 & 552 & 372 & 474 & 3,073 \\
\hline & $(825)$ & $(628)$ & $(570)$ & $(841)$ & $(687)$ & $(700)$ & $(703)$ & \\
\hline \# Obs. & 590 & 842 & 1,008 & 643 & 657 & 359 & 4,099 & 4,099 \\
\hline \multicolumn{9}{|c|}{$\begin{array}{l}\text { Notes: Mean and standard deviation (in parentheses) for the three main variables reported on con- } \\
\text { tracts. Differences in the number of observations across variables are due to missing information. } \\
\text { The number of observations for a given day include all contracts with information for at least one } \\
\text { variable. The label HTO refers to hard-to-observe measures and ETO refers to easy-to-observe }\end{array}$} \\
\hline
\end{tabular}


TABle 3. Day-of-the-week effects

\begin{tabular}{|c|c|c|c|c|c|c|}
\hline $\begin{array}{l}\text { Dep. Variable: } \\
\text { Log(kWh+Nat. } \\
\text { Gas/month) }\end{array}$ & $\begin{array}{l}\text { Monday } \\
\text { Effect }\end{array}$ & $\begin{array}{c}\text { Tuesday } \\
\text { Effect }\end{array}$ & $\begin{array}{c}\text { Wednesday } \\
\text { Effect }\end{array}$ & $\begin{array}{c}\text { Thursday } \\
\text { Effect }\end{array}$ & $\begin{array}{l}\text { Friday } \\
\text { Effect }\end{array}$ & $\begin{array}{c}\text { Friday }+ \text { WE } \\
\text { Effect }\end{array}$ \\
\hline $\mathrm{HTO}=1$ & $\begin{array}{l}-0.0254^{*} \\
(0.0152)\end{array}$ & $\begin{array}{l}-0.0299^{*} \\
(0.0165)\end{array}$ & $\begin{array}{l}-0.0292^{*} \\
(0.0168)\end{array}$ & $\begin{array}{c}-0.0400^{* *} \\
(0.0165)\end{array}$ & $\begin{array}{c}-0.0507^{* * *} \\
(0.0169)\end{array}$ & $\begin{array}{c}-0.0507^{* * *} \\
(0.0169)\end{array}$ \\
\hline $\mathrm{ETO}=1$ & $\begin{array}{c}-0.0561^{* * *} \\
(0.00928)\end{array}$ & $\begin{array}{c}-0.0617^{* * *} \\
(0.00970)\end{array}$ & $\begin{array}{c}-0.0419^{* * *} \\
(0.00977)\end{array}$ & $\begin{array}{c}-0.0613^{* * *} \\
(0.00941)\end{array}$ & $\begin{array}{c}-0.0586^{* * *} \\
(0.00916)\end{array}$ & $\begin{array}{c}-0.0586^{* * *} \\
(0.00916)\end{array}$ \\
\hline $\begin{array}{c}\mathrm{HTO}=1 \mathrm{X} \\
\text { Monday }\end{array}$ & $\begin{array}{l}-0.0508 \\
(0.0469)\end{array}$ & & & & & \\
\hline $\begin{array}{c}\mathrm{ETO}=1 \mathrm{X} \\
\text { Monday }\end{array}$ & $\begin{array}{l}-0.00151 \\
(0.0183)\end{array}$ & & & & & \\
\hline $\begin{array}{c}\mathrm{HTO}=1 \mathrm{X} \\
\text { Tuesday }\end{array}$ & & $\begin{array}{l}-0.0266 \\
(0.0336)\end{array}$ & & & & \\
\hline $\begin{array}{c}\text { ETO }=1 \mathrm{X} \\
\text { Tuesday }\end{array}$ & & $\begin{array}{c}0.0223 \\
(0.0159)\end{array}$ & & & & \\
\hline $\mathrm{HTO}=1 \mathrm{X}$ & & & -0.0271 & & & \\
\hline Wednesday & & & $(0.0307)$ & & & \\
\hline $\begin{array}{l}\mathrm{ETO}=1 \mathrm{X} \\
\text { Wednesday }\end{array}$ & & & $\begin{array}{c}-0.0480^{* * *} \\
(0.0159)\end{array}$ & & & \\
\hline $\mathrm{HTO}=1 \mathrm{X}$ & & & & 0.0259 & & \\
\hline Thursday & & & & $(0.0334)$ & & \\
\hline $\mathrm{ETO}=1 \mathrm{X}$ & & & & 0.0303 & & \\
\hline Thursday & & & & $(0.0186)$ & & \\
\hline $\mathrm{HTO}=1 \mathrm{X}$ & & & & & $0.0720^{* *}$ & \\
\hline Friday & & & & & $(0.0318)$ & \\
\hline $\mathrm{ETO}=1 \mathrm{X}$ & & & & & 0.0149 & \\
\hline Friday & & & & & $(0.0218)$ & \\
\hline $\mathrm{HTO}=1 \mathrm{X}$ & & & & & & $0.0581^{* *}$ \\
\hline Friday + WE & & & & & & $(0.0274)$ \\
\hline $\mathrm{ETO}=1 \mathrm{X}$ & & & & & & -0.0528 \\
\hline Friday + WE & & & & & & $(0.0328)$ \\
\hline $\mathrm{HTO}=1 \mathrm{X}$ & 0.00916 & 0.0136 & 0.0132 & 0.0238 & 0.0345 & \\
\hline WE & $(0.0391)$ & $(0.0399)$ & $(0.0401)$ & $(0.0399)$ & $(0.0400)$ & \\
\hline $\mathrm{ETO}=1 \mathrm{X}$ & -0.0157 & -0.0102 & -0.0296 & -0.0105 & -0.0132 & \\
\hline $\mathrm{WE}$ & $(0.0286)$ & $(0.0287)$ & $(0.0287)$ & $(0.0286)$ & $(0.0285)$ & \\
\hline Observations & 684,015 & 684,015 & 684,015 & 684,015 & 684,015 & 684,015 \\
\hline R-squared & 0.647 & 0.647 & 0.647 & 0.647 & 0.647 & 0.647 \\
\hline
\end{tabular}


TABLE 4. Gap Realized-Predicted Savings Without Friday-Effect

\begin{tabular}{lcccc}
\hline & $\begin{array}{c}\text { Realized } \\
\text { Savings } \\
\mathrm{kWh} / \text { month }\end{array}$ & $\begin{array}{c}\text { Realized } \\
\text { Savings }\end{array}$ & $\begin{array}{c}\text { Predicted } \\
\text { SWh/year }\end{array}$ & $\begin{array}{c}\text { MWh/year } \\
\text { MWhicted-Realized }\end{array}$ \\
HTO Mon-Th & 90.65 & 1.088 & 1.21 & Savings \\
HTO Mon-Fri & 74.29 & 0.891 & 1.24 & 0.122 \\
\hline Difference $(\%)$ & -22.0 & -22.0 & 2.42 & 0.349 \\
\hline
\end{tabular}

Notes: The realized savings in the first column are computed after controlling for the Friday effect. The realized savings in the second are not controlled for the Friday effect. Estimates are reported for hard-to-observe measures only. Other regression estimates are provided in the Appendix (Table 7). Controlling for the Friday effect reduces the discrepancy between realized and predicted savings by $65 \%$. 
TABle 5. Scenarios for sensitivity analysis

\begin{tabular}{|c|c|c|c|c|c|c|}
\hline Scenario & $\begin{array}{l}\text { Parameter } \\
\text { varied }\end{array}$ & $\begin{array}{l}\text { Reference } \\
\text { value }\end{array}$ & $\begin{array}{l}\text { Scenario } \\
\text { value }\end{array}$ & $\begin{array}{l}\text { Scenario } \\
\text { interpretation }\end{array}$ & $\begin{array}{l}\text { Nature of the barrier } \\
\text { to efficiency }\end{array}$ & $\begin{array}{l}\text { Included in } \\
\text { sufficient } \\
\text { statistic? }\end{array}$ \\
\hline "High efficiency" & $G_{\max }$ & $15 \%$ & $30 \%$ & $\begin{array}{l}\text { Upper range of the po- } \\
\text { tential for energy effi- } \\
\text { ciency claimed by engi- } \\
\text { neering studies, manu- } \\
\text { facturers, etc. }\end{array}$ & Nonmarket failure & Yes \\
\hline "Low energy price" & $p$ & $\$ 10.5 / \mathrm{MCF}$ & $\$ 6.3 / \mathrm{MCF}$ & $\begin{array}{l}\text { Removal of a } 40 \% \\
\text { mark-up associated } \\
\text { with average cost } \\
\text { pricing of natural gas, } \\
\text { as estimated by Davis } \\
\text { and Muehlegger (2010) }\end{array}$ & $\begin{array}{l}\text { Market failure (price dis- } \\
\text { tortion) }\end{array}$ & Yes \\
\hline "Low capitalization" & $l$ & 35 years & 10 years & $\begin{array}{l}\text { Homeowners do not } \\
\text { value energy savings } \\
\text { beyond the typical } \\
\text { length of ownership of } \\
\text { a dwelling }\end{array}$ & $\begin{array}{l}\text { Market failure (informa- } \\
\text { tion asymmetry) }\end{array}$ & Yes \\
\hline "High discount rate" & $r$ & $7 \%$ & $20 \%$ & $\begin{array}{lr}\text { Typical } & \text { under- } \\
\text { valuation found in } \\
\text { empirical } \\
\text { of energy } \\
\begin{array}{l}\text { defficiency } \\
\text { decisions }\end{array}\end{array}$ & Behavioral anomaly & Yes \\
\hline "High technology cost" & $\delta$ & 1,024 & 3,000 & $\begin{array}{l}\text { The total cost for } \\
\text { the highest quality is } \\
\$ 3,500 \text {, which matches } \\
\text { that faced by the } 99 \text { th } \\
\text { percentile of the GRU } \\
\text { dataset }\end{array}$ & Nonmarket failure & Yes \\
\hline $\begin{array}{l}\text { "High heating valua- } \\
\text { tion" }\end{array}$ & $V_{\max }$ & $\$ 2,816$ & $\$ 4,000$ & $\begin{array}{l}6 \% \text { of median income } \\
\text { dedicated to heating }\end{array}$ & Nonmarket failure & No \\
\hline "Low heterogeneity" & $\sigma$ & 1 & 0.25 & $\begin{array}{l}\text { Narrow distribution, } \\
\text { with thermostat set- } \\
\text { tings ranging from } \\
68^{\circ} \mathrm{F} \text { (5th percentile) } \\
\text { to } 70^{\circ} \mathrm{F} \text { (95th per- } \\
\text { centile) }\end{array}$ & Nonmarket failure & No \\
\hline
\end{tabular}


TABLE 6. Simulation results, averaged over the population of total mass 1

\begin{tabular}{|c|c|c|c|c|c|c|c|c|}
\hline \multirow[b]{2}{*}{ Model output } & \multirow[b]{2}{*}{ Unit } & \multicolumn{4}{|c|}{ Without Pigouvian price } & \multicolumn{3}{|c|}{ With Pigouvian price } \\
\hline & & $\begin{array}{l}\text { Before } \\
\text { investment }\end{array}$ & $\begin{array}{l}\text { Asymmetric } \\
\text { informa- } \\
\text { tion }\end{array}$ & $\begin{array}{l}\text { Perfect in- } \\
\text { formation }\end{array}$ & $\begin{array}{l}\text { Optimal in- } \\
\text { surance }\end{array}$ & $\begin{array}{l}\text { Before } \\
\text { investment }\end{array}$ & $\begin{array}{l}\text { Asymmetric } \\
\text { informa- } \\
\text { tion }\end{array}$ & $\begin{array}{l}\text { Perfect in- } \\
\text { formation }\end{array}$ \\
\hline $\begin{array}{l}\text { Welfare improvement, without } \\
\text { externalities }\end{array}$ & $\$$ & 0 & 11 & 364 & 176 & -196 & -185 & 180 \\
\hline $\begin{array}{l}\text { Welfare improvement, with ex- } \\
\text { ternalities }\end{array}$ & $\$$ & 0 & 24 & 531 & 35 & 222 & 247 & 741 \\
\hline $\begin{array}{l}\text { Homeowners' equilibrium tem- } \\
\text { perature }\end{array}$ & ${ }^{\circ} \mathrm{F}$ & 68.9 & 68.9 & 69.2 & 69.8 & 67.7 & 67.7 & 68.0 \\
\hline $\begin{array}{l}\text { Annual natural gas use for } \\
\text { space heating }\end{array}$ & $\mathrm{MCF}$ & 50.2 & 50.0 & 47.4 & 52.6 & 43.1 & 42.9 & 40.7 \\
\hline $\begin{array}{l}\text { Annual natural gas expendi- } \\
\text { ture }\end{array}$ & $\$$ & 527 & 525 & 498 & 552 & 453 & 451 & 427 \\
\hline Annual $\mathrm{CO}_{2}$ emissions & $\mathrm{tCO}_{2}$ & 2.6 & 2.6 & 2.4 & 2.7 & 2.2 & 2.2 & 2.1 \\
\hline $\begin{array}{l}\text { Annual external cost of } \mathrm{CO}_{2} \\
\text { emissions }\end{array}$ & $\$$ & 85 & 84 & 80 & 89 & 73 & 73 & 69 \\
\hline $\begin{array}{l}\text { Contractor's equilibrium qual- } \\
\text { ity }\end{array}$ & & & $0 \%$ & $41 \%$ & $16 \%$ & & $0 \%$ & $46 \%$ \\
\hline Energy efficiency of insulation & & & $0.5 \%$ & $8.1 \%$ & $4.0 \%$ & & $0.7 \%$ & $8.6 \%$ \\
\hline Rebound effect & & & $9 \%$ & $31 \%$ & $219 \%$ & & $21 \%$ & $34 \%$ \\
\hline $\begin{array}{l}\text { Cutoff type of the marginal } \\
\text { participant }\end{array}$ & & & 1.00 & 0.16 & 0.32 & & 0.67 & 0.18 \\
\hline Participation rate & & & $50 \%$ & $97 \%$ & $87 \%$ & & $66 \%$ & $96 \%$ \\
\hline Zero-profit insulation price & $\$$ & & 509 & 690 & 540 & & 509 & 739 \\
\hline Homeowner's net present value & $\$$ & & 22 & 377 & 202 & & 37 & 542 \\
\hline Insurance premium & & & & & 1,725 & & & \\
\hline Insurance optimal coverage & & & & & $18 \%$ & & & \\
\hline
\end{tabular}

Notes: "Energy efficiency" is averaged over the whole population. The average over participants is obtained by dividing "Energy Efficiency" by "Participation rate". Welfare improvements are measured against present discounted welfare before investment, without a Pigouvian price $(\$ 49,433$ without externalities, $\$ 46,463$ with externalities). 


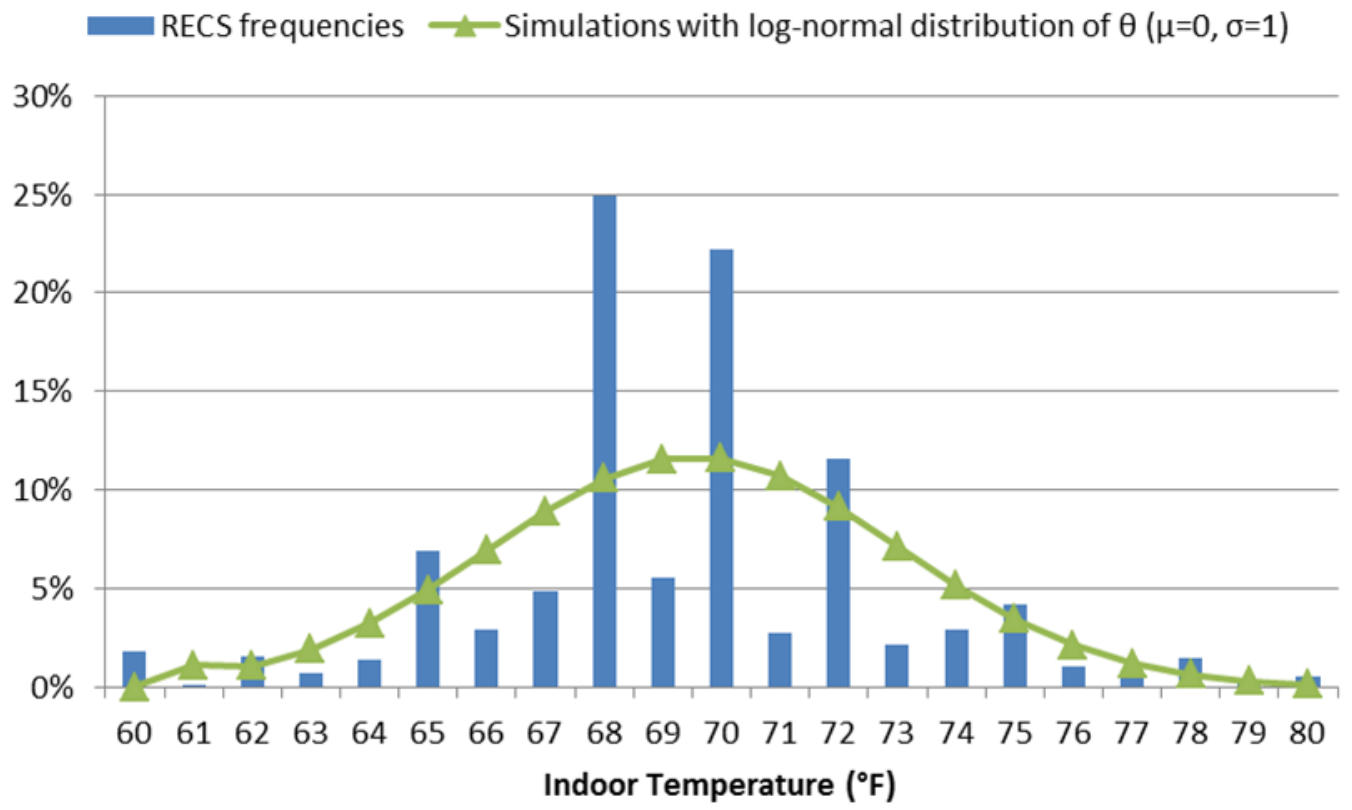

Figure 1. Model fit to RECS temperature data. The simulated probability distribution is calculated with the triangle method. 


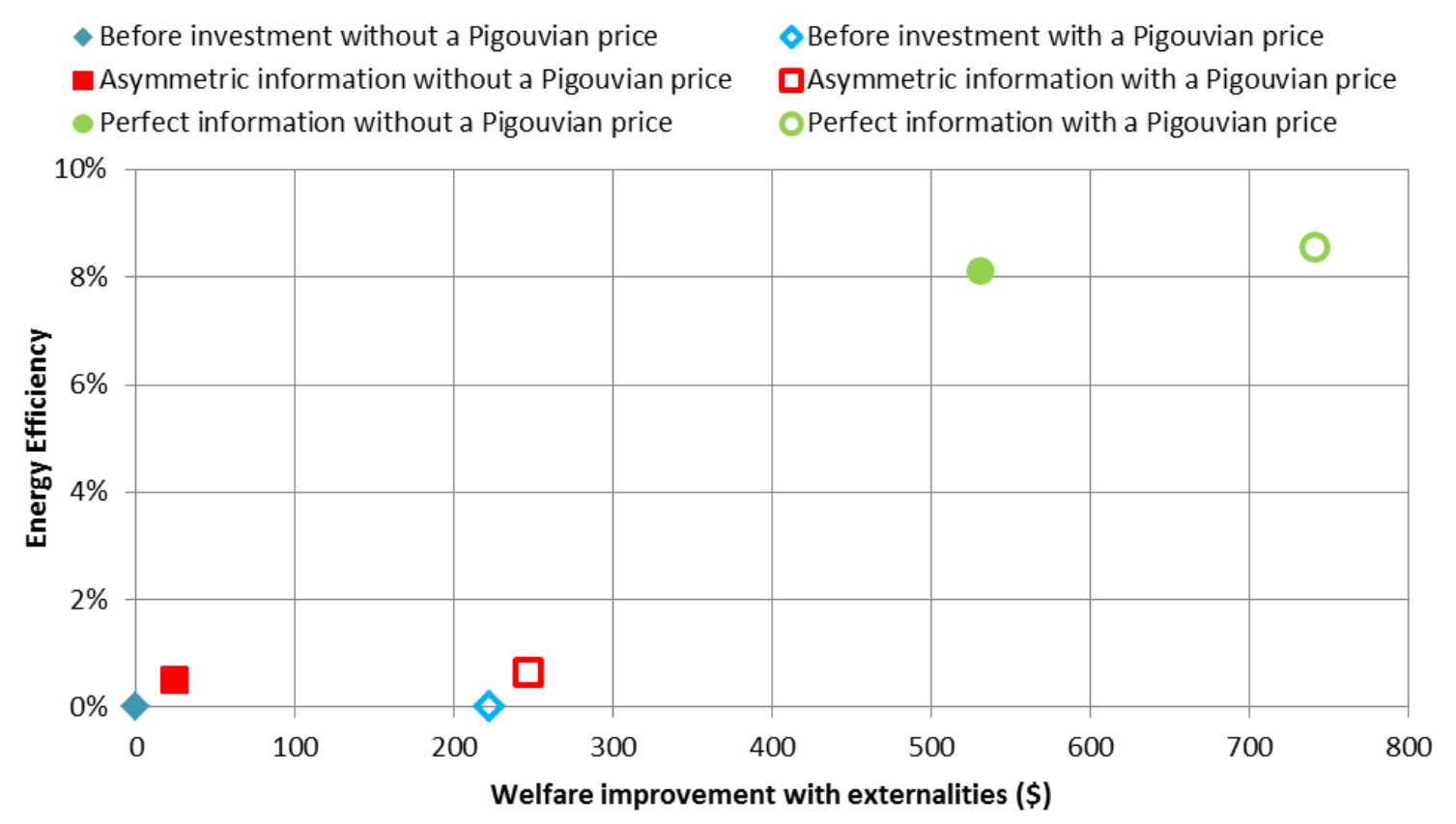

FIGURE 2. Energy efficiency gap in the reference scenario. The horizontal axis represents average present discounted welfare for different equilibria, with energy-use externalities valued at $\$ 33 / \mathrm{tCO}_{2}$. The vertical axis represents average energy efficiency, with non-participating homeowners getting $0 \%$. 

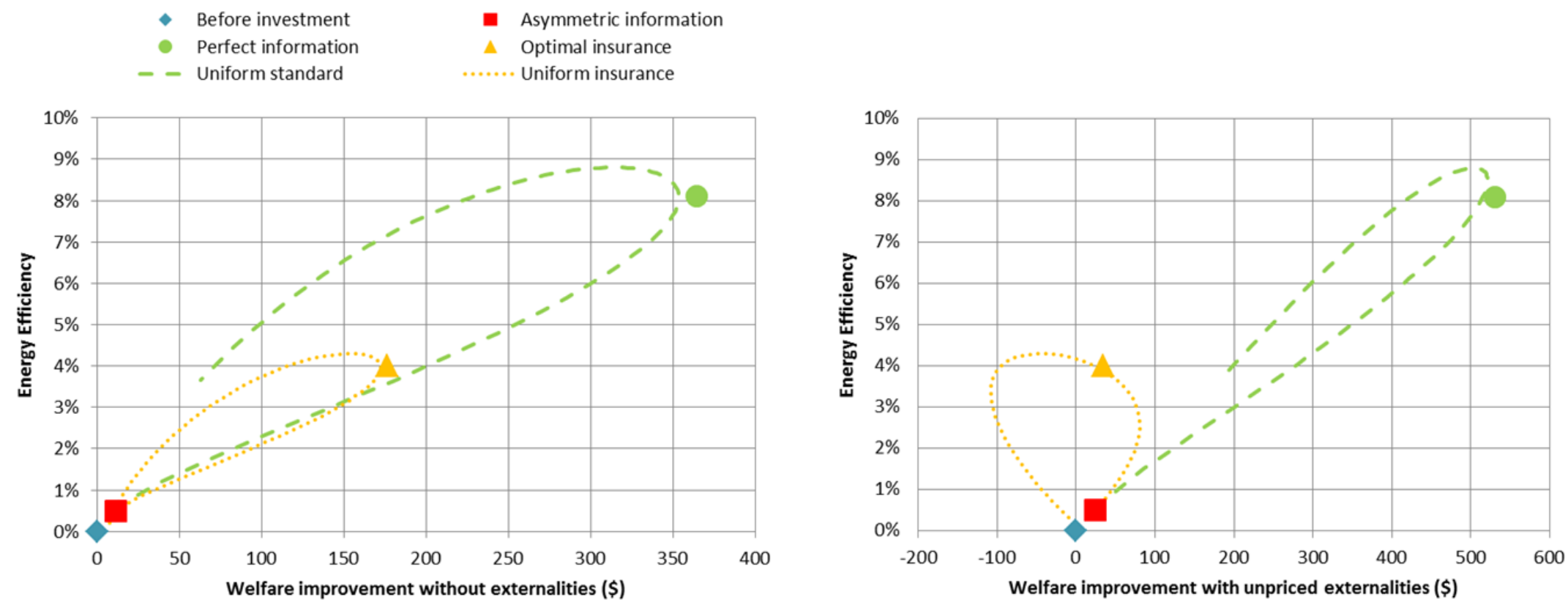

FIGURE 3. Impact of policies in the reference scenario. Uniform insurance draw a parametric curve with coverage increasing counter-clockwise by $1 \%$, from $0 \%$ to $100 \%$. Similarly, uniform standards draw a parametric curve with mandated quality increasing counter-clockwise by $1 \%$, from $0 \%$ to $100 \%$. The best uniform insurance has a coverage of $22 \%$ without externalities and $10 \%$ otherwise. The best uniform standard mandates a quality of $43 \%$ without externalities and $49 \%$ otherwise. 


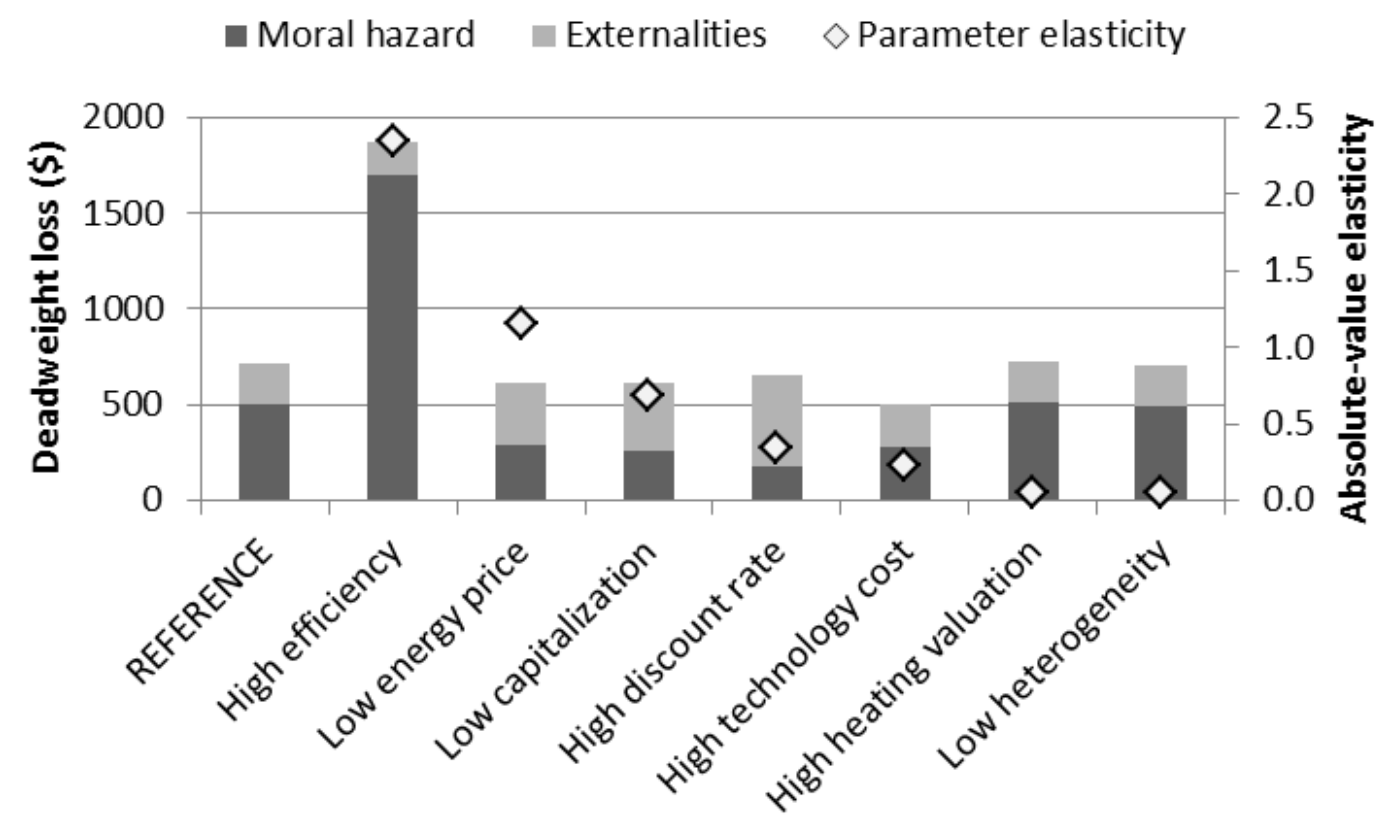

Figure 4. Sensitivity analysis. The deadweight loss from moral hazard is calculated as the welfare difference between perfect and asymmetric information, both with unpriced externalities; the externalities are calculated as the welfare difference between priced and unpriced externalities, both under perfect information. Elasticies, which measures each parameter's influence, are calculated as the percentage change in the deadweight loss due to moral hazard divided by the percentage change in parameter value. They are all positive, except for the "High discount rate" and "High technology cost" scenarios. They are reported in the figure in absolute value. Scenario assumptions are detailed in Table 5 . 


\section{Appendix: Additional Regression Result}

Table 7. Realized Energy Savings: Controlling for Friday-Effect

\begin{tabular}{|c|c|c|}
\hline $\begin{array}{l}\text { Dep. Variable: } \\
\text { kWh+Nat. } \\
\text { Gas/month }\end{array}$ & $\begin{array}{l}\text { Controlling for } \\
\text { Friday-Effect }\end{array}$ & $\begin{array}{l}\text { Not Controlling for } \\
\text { Friday-Effect }\end{array}$ \\
\hline $\mathrm{MH}=1$ & $\begin{array}{c}-90.65^{* * *} \\
(27.80)\end{array}$ & $\begin{array}{c}-74.29^{* * *} \\
(23.33)\end{array}$ \\
\hline $\mathrm{NoMH}=1$ & $\begin{array}{c}-103.3^{* * *} \\
(13.46)\end{array}$ & $\begin{array}{c}-107.8^{* * *} \\
(12.59)\end{array}$ \\
\hline $\begin{array}{c}\mathrm{MH}=1 \mathrm{X} \\
\text { Friday }\end{array}$ & $\begin{array}{c}74.34 \\
(46.29)\end{array}$ & \\
\hline $\begin{array}{c}\mathrm{NoMH}=1 \mathrm{X} \\
\text { Friday }\end{array}$ & $\begin{array}{l}-29.71 \\
(37.15)\end{array}$ & \\
\hline $\begin{array}{c}M H=1 X \\
W E\end{array}$ & $\begin{array}{l}120.9^{* *} \\
(49.90)\end{array}$ & $\begin{array}{l}104.8^{* *} \\
(47.28)\end{array}$ \\
\hline $\begin{array}{l}\mathrm{NoMH}=1 \mathrm{X} \\
\mathrm{WE}\end{array}$ & $\begin{array}{l}-63.52 \\
(58.67)\end{array}$ & $\begin{array}{l}-58.86 \\
(58.50)\end{array}$ \\
\hline Constant & $\begin{array}{c}1,565^{* * *} \\
(7.883)\end{array}$ & $\begin{array}{c}1,565^{* * *} \\
(7.882)\end{array}$ \\
\hline Observations & 692,879 & 692,879 \\
\hline R-squared & 0.679 & 0.679 \\
\hline
\end{tabular}


TABLE 8. Day-of-the-Week Effect: No Low-Income Grant and Home Performance Projects

\begin{tabular}{|c|c|c|c|c|c|c|}
\hline $\begin{array}{l}\text { Dep. Variable: } \\
\text { Log(kWh+Nat. } \\
\text { Gas/month) }\end{array}$ & $\begin{array}{c}\text { Monday } \\
\text { Effect }\end{array}$ & $\begin{array}{c}\text { Tuesday } \\
\text { Effect }\end{array}$ & $\begin{array}{c}\text { Wednesday } \\
\text { Effect }\end{array}$ & $\begin{array}{c}\text { Thursday } \\
\text { Effect }\end{array}$ & $\begin{array}{l}\text { Friday } \\
\text { Effect }\end{array}$ & $\begin{array}{c}\text { Friday+WE } \\
\text { Effect }\end{array}$ \\
\hline $\mathrm{MH}=1$ & $\begin{array}{l}-0.0203 \\
(0.0155)\end{array}$ & $\begin{array}{l}-0.0247 \\
(0.0167)\end{array}$ & $\begin{array}{l}-0.0241 \\
(0.0169)\end{array}$ & $\begin{array}{c}-0.0349^{* *} \\
(0.0166)\end{array}$ & $\begin{array}{c}-0.0455^{* * *} \\
(0.0171)\end{array}$ & $\begin{array}{c}-0.0455^{* * *} \\
(0.0171)\end{array}$ \\
\hline $\mathrm{NoMH}=1$ & $\begin{array}{c}-0.0502^{* * *} \\
(0.0108)\end{array}$ & $\begin{array}{c}-0.0552^{* * *} \\
(0.0114)\end{array}$ & $\begin{array}{c}-0.0285^{* *} \\
(0.0116)\end{array}$ & $\begin{array}{c}-0.0523^{* * *} \\
(0.0109)\end{array}$ & $\begin{array}{c}-0.0521^{* * *} \\
(0.0105)\end{array}$ & $\begin{array}{c}-0.0521^{* * *} \\
(0.0105)\end{array}$ \\
\hline $\begin{array}{l}\mathrm{MH}=1 \mathrm{X} \\
\text { Monday }\end{array}$ & $\begin{array}{l}-0.0507 \\
(0.0469)\end{array}$ & & & & & \\
\hline $\begin{array}{c}\text { NoMH }=1 \mathrm{X} \\
\text { Monday }\end{array}$ & $\begin{array}{c}0.0134 \\
(0.0223)\end{array}$ & & & & & \\
\hline $\begin{array}{l}\mathrm{MH}=1 \mathrm{X} \\
\text { Tuesday }\end{array}$ & & $\begin{array}{l}-0.0266 \\
(0.0336)\end{array}$ & & & & \\
\hline $\mathrm{NoMH}=1 \mathrm{X}$ & & 0.0266 & & & & \\
\hline Tuesday & & $(0.0190)$ & & & & \\
\hline $\mathrm{MH}=1 \mathrm{X}$ & & & -0.0270 & & & \\
\hline Wednesday & & & $(0.0307)$ & & & \\
\hline NoMH=1 X & & & $-0.0598^{* * *}$ & & & \\
\hline Wednesday & & & $(0.0187)$ & & & \\
\hline $\mathrm{MH}=1 \mathrm{X}$ & & & & 0.0259 & & \\
\hline Thursday & & & & $(0.0334)$ & & \\
\hline $\mathrm{NoMH}=1 \mathrm{X}$ & & & & 0.0276 & & \\
\hline Thursday & & & & $(0.0238)$ & & \\
\hline $\mathrm{MH}=1 \mathrm{X}$ & & & & & $0.0719^{* *}$ & \\
\hline Friday & & & & & $(0.0318)$ & \\
\hline $\mathrm{NoMH}=1 \mathrm{X}$ & & & & & 0.0265 & \\
\hline Friday & & & & & $(0.0273)$ & \\
\hline $\mathrm{MH}=1 \mathrm{X}$ & & & & & & $0.0580^{* *}$ \\
\hline Friday + WE & & & & & & $(0.0274)$ \\
\hline $\begin{array}{l}\text { NoMH }=1 \mathrm{X} \\
\text { Friday }+\mathrm{WE}\end{array}$ & & & & & & $\begin{array}{l}-0.0414 \\
(0.0350)\end{array}$ \\
\hline $\begin{array}{l}\mathrm{MH}=1 \mathrm{X} \\
\mathrm{WE}\end{array}$ & $\begin{array}{l}0.00896 \\
(0.0391)\end{array}$ & $\begin{array}{c}0.0134 \\
(0.0399)\end{array}$ & $\begin{array}{c}0.0130 \\
(0.0401)\end{array}$ & $\begin{array}{c}0.0236 \\
(0.0399)\end{array}$ & $\begin{array}{c}0.0342 \\
(0.0400)\end{array}$ & \\
\hline $\begin{array}{l}\text { NoMH }=1 \mathrm{X} \\
\mathrm{WE}\end{array}$ & $\begin{array}{c}-0.000968 \\
(0.0326)\end{array}$ & $\begin{array}{l}0.00402 \\
(0.0328)\end{array}$ & $\begin{array}{l}-0.0223 \\
(0.0328)\end{array}$ & $\begin{array}{l}0.00115 \\
(0.0326)\end{array}$ & $\begin{array}{l}0.00101 \\
(0.0325)\end{array}$ & \\
\hline Observations & 540,229 & 540,229 & 540,229 & 540,229 & 540,229 & 540,229 \\
\hline$R^{2}$ & 0.648 & 0.648 & 0.648 & 0.648 & 0.648 & 0.648 \\
\hline
\end{tabular}


TABLE 9. Day-of-the-Week Effect: Level

\begin{tabular}{|c|c|c|c|c|c|c|}
\hline $\begin{array}{l}\text { Dep. Variable: } \\
\text { kWh+Nat. } \\
\text { Gas/month }\end{array}$ & $\begin{array}{c}\text { Monday } \\
\text { Effect }\end{array}$ & $\begin{array}{c}\text { Tuesday } \\
\text { Effect }\end{array}$ & $\begin{array}{c}\text { Wednesday } \\
\text { Effect }\end{array}$ & $\begin{array}{c}\text { Thursday } \\
\text { Effect }\end{array}$ & $\begin{array}{l}\text { Friday } \\
\text { Effect }\end{array}$ & $\begin{array}{c}\text { Friday }+ \text { WE } \\
\text { Effect }\end{array}$ \\
\hline $\mathrm{MH}=1$ & $\begin{array}{c}-63.09^{* * *} \\
(23.40)\end{array}$ & $\begin{array}{c}-69.09^{* * *} \\
(26.01)\end{array}$ & $\begin{array}{c}-70.30^{* * *} \\
(27.03)\end{array}$ & $\begin{array}{c}-79.05^{* * *} \\
(26.60)\end{array}$ & $\begin{array}{c}-90.65^{* * *} \\
(27.80)\end{array}$ & $\begin{array}{c}-90.68^{* * *} \\
(27.80)\end{array}$ \\
\hline $\mathrm{NoMH}=1$ & $\begin{array}{c}-104.8^{* * *} \\
(13.50)\end{array}$ & $\begin{array}{c}-118.5^{* * *} \\
(14.37)\end{array}$ & $\begin{array}{c}-99.46^{* * *} \\
(14.79)\end{array}$ & $\begin{array}{c}-112.6^{* * *} \\
(14.01)\end{array}$ & $\begin{array}{c}-103.3^{* * *} \\
(13.46)\end{array}$ & $\begin{array}{c}-103.4^{* * *} \\
(13.46)\end{array}$ \\
\hline $\begin{array}{l}\mathrm{MH}=1 \mathrm{X} \\
\text { Monday }\end{array}$ & $\begin{array}{l}-59.26 \\
(82.87)\end{array}$ & & & & & \\
\hline $\begin{array}{c}\text { NoMH }=1 \mathrm{X} \\
\text { Monday }\end{array}$ & $\begin{array}{l}-20.63 \\
(32.09)\end{array}$ & & & & & \\
\hline $\begin{array}{c}\text { MH=1 X } \\
\text { Tuesday }\end{array}$ & $\begin{array}{l}93.50^{* *} \\
(46.70)\end{array}$ & $\begin{array}{l}99.45^{* *} \\
(48.65)\end{array}$ & $\begin{array}{l}100.9^{* *} \\
(49.42)\end{array}$ & $\begin{array}{l}109.5^{* *} \\
(49.09)\end{array}$ & $\begin{array}{l}120.9^{* *} \\
(49.90)\end{array}$ & \\
\hline $\begin{array}{c}\text { NoMH }=1 \mathrm{X} \\
\text { Tuesday }\end{array}$ & $\begin{array}{l}-61.86 \\
(58.77)\end{array}$ & $\begin{array}{l}-48.22 \\
(58.96)\end{array}$ & $\begin{array}{l}-66.97 \\
(58.97)\end{array}$ & $\begin{array}{l}-53.98 \\
(58.78)\end{array}$ & $\begin{array}{l}-63.52 \\
(58.67)\end{array}$ & \\
\hline $\begin{array}{l}\mathrm{MH}=1 \mathrm{X} \\
\text { Wednesday }\end{array}$ & & $\begin{array}{l}-27.53 \\
(60.69)\end{array}$ & & & & \\
\hline $\mathrm{NoMH}=1 \mathrm{X}$ & & 44.84 & & & & \\
\hline Wednesday & & $(27.67)$ & & & & \\
\hline $\mathrm{MH}=1 \mathrm{X}$ & & & -18.93 & & & \\
\hline Thursday & & & $(50.94)$ & & & \\
\hline $\mathrm{NoMH}=1 \mathrm{X}$ & & & -27.49 & & & \\
\hline Thursday & & & $(27.61)$ & & & \\
\hline $\mathrm{MH}=1 \mathrm{X}$ & & & & 24.42 & & \\
\hline Friday & & & & $(54.46)$ & & \\
\hline $\begin{array}{l}\text { NoMH }=1 \mathrm{X} \\
\text { Friday }\end{array}$ & & & & $\begin{array}{c}29.64 \\
(32.15)\end{array}$ & & \\
\hline $\mathrm{MH}=1 \mathrm{X}$ & & & & & 74.34 & \\
\hline Friday $+\mathrm{WE}$ & & & & & $(46.29)$ & \\
\hline $\mathrm{NoMH}=1 \mathrm{X}$ & & & & & -29.71 & \\
\hline Friday $+\mathrm{WE}$ & & & & & $(37.15)$ & \\
\hline $\mathrm{MH}=1 \mathrm{X}$ & & & & & & $91.75^{* *}$ \\
\hline WE & & & & & & $(39.67)$ \\
\hline $\begin{array}{l}\mathrm{NoMH}=1 \mathrm{X} \\
\mathrm{WE}\end{array}$ & & & & & & $\begin{array}{c}-133.0^{* * *} \\
(51.41)\end{array}$ \\
\hline Constant & $\begin{array}{c}1,565^{* * *} \\
(7.881)\end{array}$ & $\begin{array}{c}1,565^{* * *} \\
(7.885)\end{array}$ & $\begin{array}{c}1,565^{* * *} \\
(7.884)\end{array}$ & $\begin{array}{c}1,565^{* * *} \\
(7.881)\end{array}$ & $\begin{array}{c}1,565^{* * *} \\
(7.883)\end{array}$ & $\begin{array}{c}1,565^{\text {*** }} \\
(7.883)\end{array}$ \\
\hline Observations & 692,879 & 692,879 & 692,879 & 692,879 & 692,879 & 692,879 \\
\hline R-squared & 0.679 & 0.679 & 0.679 & 0.679 & 0.679 & 0.679 \\
\hline
\end{tabular}

